\title{
Solid Lipid Nanoparticles (SLNs): An Advanced Drug Delivery System Targeting Brain through BBB
}

\author{
Mantosh Kumar Satapathy ${ }^{1}\left(\mathbb{D}\right.$, Ting-Lin Yen ${ }^{1,2,+}{ }^{\mathbb{D}}$, Jing-Shiun Jan ${ }^{1,+}$, Ruei-Dun Tang ${ }^{1,3}$, Jia-Yi Wang ${ }^{3,4,5}{ }^{(D)}$, \\ Rajeev Taliyan ${ }^{6}$ and Chih-Hao Yang ${ }^{1,5, *(D)}$
}

1 Department of Pharmacology, School of Medicine, College of Medicine, Taipei Medical University, No. 250, Wu Hsing St., Taipei 110, Taiwan; mantoshbiotech@gmail.com (M.K.S.); d119096015@tmu.edu.tw (T.-L.Y.); d119101004@tmu.edu.tw (J.-S.J.); tang0803@tmu.edu.tw (R.-D.T.)

2 Department of Medical Research, Cathay General Hospital, Taipei 22174, Taiwan

3 Graduate Institute of Medical Sciences, College of Medicine, Taipei Medical University, No. 250, Wu Hsing St., Taipei 110, Taiwan; jywang2010@tmu.edu.tw

4 Department of Neurosurgery, Taipei Medical University Hospital, Taipei 110, Taiwan

5 Neuroscience Research Center, Taipei Medical University, Taipei 110, Taiwan

6 Department of Pharmacy, Neuropsychopharmacology Division, Birla Institute of Technology and Science, Pilani 333031, India; taliyanraja@gmail.com

* Correspondence: chyang@tmu.edu.tw; Tel.: +886-2-2736-1661 (ext. 3197)

+ These authors contributed equally to this work.

check for updates

Citation: Satapathy, M.K.; Yen, T.-L.; Jan, J.-S.; Tang, R.-D.; Wang, J.-Y.; Taliyan, R.; Yang, C.-H. Solid Lipid Nanoparticles (SLNs): An Advanced Drug Delivery System Targeting Brain through BBB. Pharmaceutics 2021, 13, 1183. https://doi.org/ 10.3390/pharmaceutics13081183

Academic Editors: Joana A. Loureiro and Maria Carmo Pereira

Received: 5 July 2021

Accepted: 27 July 2021

Published: 31 July 2021

Publisher's Note: MDPI stays neutral with regard to jurisdictional claims in published maps and institutional affiliations.

Copyright: (c) 2021 by the authors. Licensee MDPI, Basel, Switzerland. This article is an open access article distributed under the terms and conditions of the Creative Commons Attribution (CC BY) license (https:/ / creativecommons.org/licenses/by/ $4.0 /)$.

\begin{abstract}
The blood-brain barrier (BBB) plays a vital role in the protection and maintenance of homeostasis in the brain. In this way, it is an interesting target as an interface for various types of drug delivery, specifically in the context of the treatment of several neuropathological conditions where the therapeutic agents cannot cross the BBB. Drug toxicity and on-target specificity are among some of the limitations associated with current neurotherapeutics. In recent years, advances in nanodrug delivery have enabled the carrier system containing the active therapeutic drug to target the signaling pathways and pathophysiology that are closely linked to central nervous system (CNS) disorders such as Alzheimer's disease (AD), Parkinson's disease (PD), Huntington's disease (HD), multiple sclerosis (MS), brain tumor, epilepsy, ischemic stroke, and neurodegeneration. At present, among the nano formulations, solid lipid nanoparticles (SLNs) have emerged as a putative drug carrier system that can deliver the active therapeutics (drug-loaded SLNs) across the BBB at the target site of the brain, offering a novel approach with controlled drug delivery, longer circulation time, target specificity, and higher efficacy, and more importantly, reducing toxicity in a biomimetic way. This paper highlights the synthesis and application of SLNs as a novel nontoxic formulation strategy to carry CNS drugs across the BBB to improve the use of therapeutics agents in treating major neurological disorders in future clinics.
\end{abstract}

Keywords: neurological disorders; BBB; nano drug delivery; SLN

\section{Introduction}

An abundance of people worldwide are affected by various chronic neurological disorders such as Alzheimer's disease (AD), Parkinson's disease (PD), brain tumors/cancers, Huntington's disease (HD), neuromuscular disease, multiple sclerosis (MS), neurodegeneration, and epilepsy, resulting in tremendous morbidity and mortality [1]. Central nervous system (CNS) diseases are most commonly characterized by an imbalance in neurological function, leading to neuronal death [2-4]. There are multiple mechanisms associated with these neuropathologies. CNS disorders are the result of mitochondrial dysfunction, the accumulation of misfolded protein, a lack of neurotrophic factor production, endogenous antioxidant enzyme activity depletion, neurotrophin deficiency, and sometimes defects at the genetic and molecular levels. Therefore, it is very challenging to find out certain specific treatment strategy to target the CNS pathologies. The blood-brain barrier (BBB) plays a 
further vital role as an obstacle for the potential drugs to cross [5]. Hence, pharmacokinetic efficacy found in existing drugs is discouraging in the treatment of brain disorders. The BBB needs to be studied in detail for the development of drug and carrier systems to deliver the drug to the brain site with long-term efficacy and less possible toxicity. Less successful treatment strategies have been developed to date for the treatment of neurodegenerative diseases [6]. Simultaneously, advanced drug delivery systems such as polymer-based nano-carrier-mediated drug delivery haves been developed as a front line clinical therapeutic method which can overcome the BBB-associated hindrances. However, the limited availability and high cost of safe polymers have limited the wide-spread application of polymeric nano-formulations in clinics [7]. Solid lipid nanoparticles (SLNs) are one of the safest and cheapest carriers of the drug, enabling the treatment of neurological disorders in a nontoxic, safe, and effective way by crossing the BBB. As SLNs' functionality and efficacy depend on their constituent, size, structure, physico-chemical properties, and the synthetic methods by which they are produced, it is necessary to shed light on the advanced production technologies used to create SLNs in the field of drug delivery. Progressively, newly formed lipid nanoparticles have overcome the shortcomings of previous SLNs [8]. The second-generation nano lipid carriers (NLCs), as modified SLNs, serve as better drug delivery carriers, overcoming limitations such as drug expulsion, and a sudden release of active drug components for brain drug delivery. Tailoring SLNs to enhance drug delivery to the brain may enable them to cross the BBB and improve the drug's bioavailability.

Therefore, it is important to explore the properties of the BBB in detail, and to ensure that SLNs and their modifications function as an appropriate nanocarrier drug delivery system, with the potential to treat neurological disorders with less toxicity and fewer side effects.

\section{Blood-Brain Barrier}

There are several anatomical and metabolic barriers present between peripheral blood circulation and the brain, such as cerebrospinal fluid (CSF), choroid plexus (CP), and the BBB. The BBB is an anatomical protective barrier to the brain which separates the brain from direct contact with the blood [9]. The BBB is a vital component of the neurovascular unit of the body, communicating CNS. At the same time, it restricts the free exchange of substances in brain cells. The main BBB components are endothelial cells, astrocytic endfeet links, basal lamina, tight junctions, and pericytes [10-12] (Figure 1). Most importantly, the BBB endothelial cells are quite different from peripheral endothelial cells. The BBB strictly controls the transportation of substances into the brain through both physical barriers, that is, tight junctions (composed of several transmembrane proteins, such as occludin, claudins, and junctional adhesion molecules (JAMs)), and the metabolic barrier (various enzymes). There are also many associated junctions and membrane systems, such as adherens, gap junctions, tight junctions, pericyte endothelial junctions, astrocyte junction, and the basement membrane. The essential neurovascular unit cell types that contribute to the functionality of the BBB are endothelial cell adhesion molecules, pericytes, smooth muscle cells, astrocytes, and micro glia, etc., which form the BBB, a complex barrier unit [13-16]. Transport through the BBB occurs based on endogenous-carrier- mediated transport (CMT) or a receptor-mediated transport (RMT) system [17], with the assistance of some major transporters, receptors, and channels in endothelial cells and pericytes. In this way, the BBB acts as a physical and metabolic barrier as well as a secretory and transport interface [18] to the brain and CNS. The BBB plays a major role in the regulated and specialized transport of several neurological factors from serum, allowing only useful and specific substances to cross through and protecting the brain from neurotoxins [5]. The selective transportation of nutrients or drugs across the $\mathrm{BBB}$ occurs through a specialized transportation across the capillary endothelial plasma membrane comprising active efflux systems, active transporters, and ectoenzymes [19]. Although many drugs are used for the treatment of neurological disorders, the specialized microvasculature of the BBB allows 
for the selection of a few medicines during systemic administration, which results in inadequate efficacy.

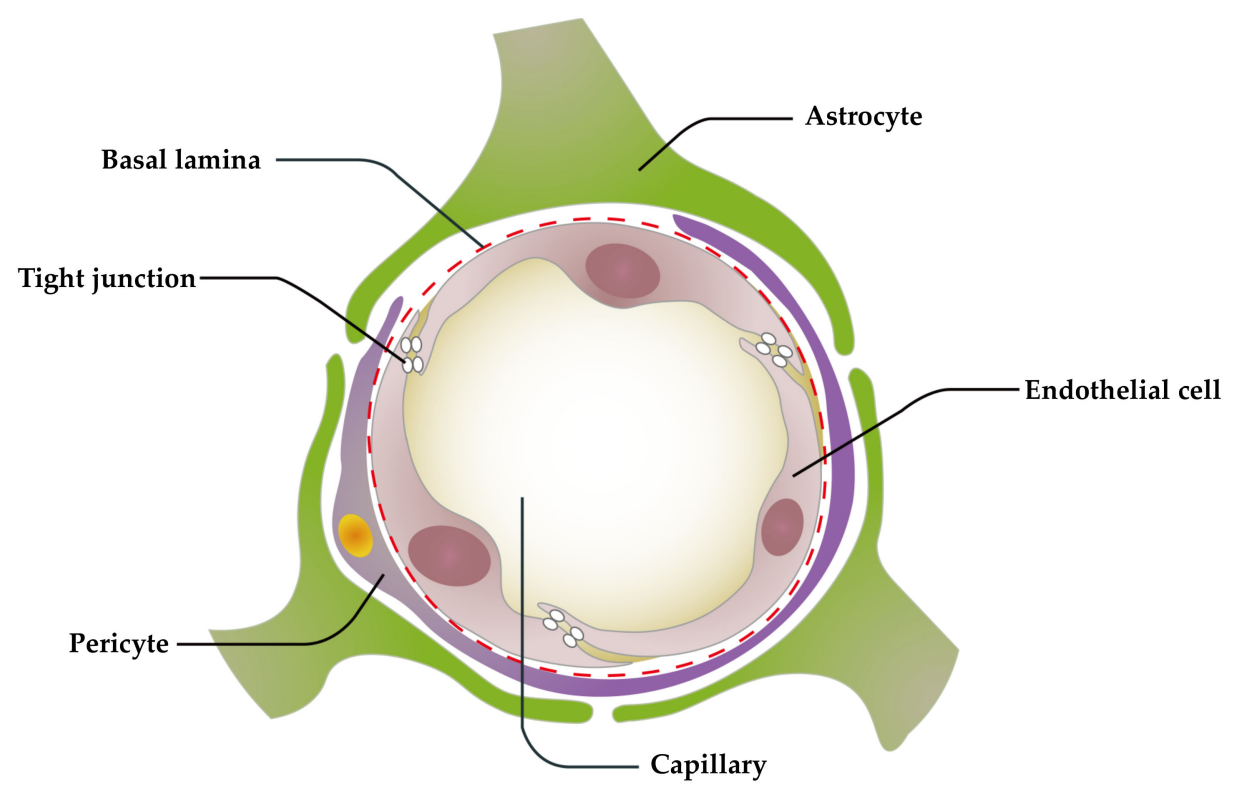

Figure 1. Blood brain barrier detailed anatomy showing capillary, tight junction, endothelial cell, pericyte, basal lamina, and astrocyte.

Several factors are responsible for drugs crossing the BBB, such as drug-related factors; molecular weight (below $400 \mathrm{Da}$ ), morphology (spherical), size (nano meter range), ionization (physiological $\mathrm{pH}$ ), lipophilicity are the major factors [20]. The associated peripheral factors such as $\log \mathrm{P} \mathrm{o} / \mathrm{w}$ value of drug ( -0.5 to 6.0$)$, enzymatic stability, plasma-proteinbinding affinity, uptake of the drug into other tissues, volume of distribution, clearance rate, and rate of oxidative metabolism by cytochrome P450 effects [20,21]. These physicochemical factors, and any other pathological abnormalities that may exist, should be taken into consideration.

The regulation of BBB transport is correlated with neuronal functions such as neural degeneration and neurogenesis and contributes to the sole function of CNS. Consequently, the $\mathrm{BBB}$ is an interesting target to focus on in the drug design process, in which the complex pathophysiology of the human brain needs to be studied, with a greater focus on the BBB in particular. A better understanding of the BBB and a focus on developing newer small molecules, advanced drugs and carriers are the goals of the current clinical research in biomedicine targeting neurological disorders.

\section{Brain Drug Delivery Strategies}

Various strategies have been developed over time to deliver active therapeutic agents to the brain to treat neurological disorders (Figure 2). A best route, the drug formulation and optimal window of administration have been the fascinating subjects in the field of brain drug delivery for treatment of neurological disorders. Generally, drugs can be delivered to the brain by local brain site injection, or via a catheter or direct drug administration following invasive surgeries. Drug-loaded polymeric biodegradable materials can be implanted for the sustained release of the drug at a specific site of the brain in this type of delivery strategy $[22,23]$. The local delivery route is among the most invasive administration routes, although very effective in animals in delivering drug formulation to brain, will fail in clinical context when treating real human (variable physiology) patients due to rapid drug degradation and clearance. Hence, steady pharmacological effect is needed with less invasive ways of drug delivery. Intranasal route of drug delivery is also promising, allowing the drug to directly reach the brain by bypassing the BBB [24-26]. The active drug, loaded in some nanocarrier system after reaching the nasal cavity, directly 
reaching the brain through the olfactory pathway and trigeminal pathway [27-29]. Still, the intranasal route is not an ideal approach due to inconsistencies in the released dose at the target site, which is solely dependent on the nature of the nasal mucosa and its interaction with the drug $[22,30]$. To date, the systemic delivery route is the most studied and acceptable strategy to deliver the drug to the brain. However, the BBB is the main obstacle in this type of drug delivery strategy. A design must be created where the active drug can be loaded inside a nontoxic and permeable nanoparticles, which can cross the BBB [31]. Moreover, there are several approaches developed to increase the permeability of the BBB such as injection of hyperosmolar mannitol [32] causing reversible disruption, or by providing ultrasound as physical stimulus [33,34]. Either way, BBB disruption led to unavoidable influx neurotoxins causing significant damage to the brain [31]. Hence, advanced drug modification strategies could be helpful to increase the ability of drugs to cross the BBB in treatment of neurological disorders avoiding neuronal dysfunction due to BBB disruption. Lipid-based nanoparticles can pass the BBB in a safe and effective manner [35].

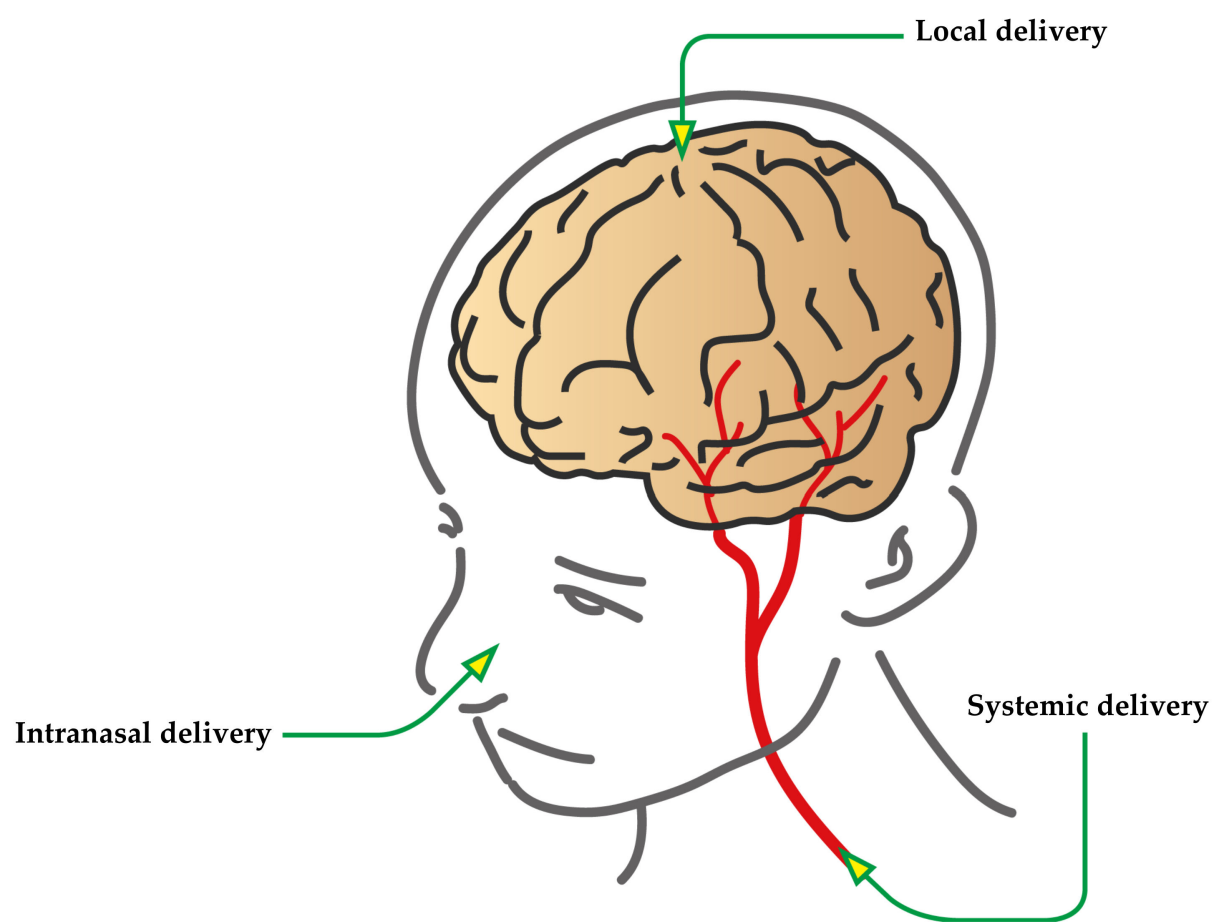

Figure 2. Different brain delivery strategies showing the major routes: local delivery, intranasal delivery, and systemic delivery.

\section{SLN as Advanced CNS Drug Delivery System}

Although there are many drug delivery-approaches for the treatment of neuronal disorders, unfortunately, ultimate success has not yet been achieved, due to a lack of target specificity, lower bioavailability, and toxicity concerns. At present, the majority of them are trial-and-error-based, and far from complete. Recent studies are inclusive of the efficiency and relative safety of receptor-mediated drug delivery regarding nutrient uptake and the recognition of specific ligands modulating endocytosis. Drug molecules modified with carrier molecules such as nanoparticles and liposomes can be delivered by the unique process of "tricking", where the receptors mediate internalization and ligands bind target cells in brain tissue [36].

In the context of carrier-mediated drug delivery, the reengineering of active drug and drug components together with carriers in pharmaceuticals that can penetrate the brain through the BBB are of interest to develop drugs that are effective in the treatment of neurological disorders. Some research findings showed that small lipophilic molecules of 
less than 400 Da can freely diffuse across the BBB endothelium [17]. Due to their size and properties, lipid nanoparticles, therefore, can interact as a drug carrier molecule with the BBB and its components, and cross the BBB. These factors will be considered in relation to drug discovery in general and CNS drug discovery in particular [37].

Over the years, nanoparticles have emerged as a suitable drug-carrier system for drug delivery in an effective and site-specific manner, due to their unique size and physicochemical properties, which enable them to cross various anatomical barriers. Furthermore, nanoparticle properties can be improved by enhancing their ability to penetrate through several anatomical barriers, releasing the drug content in sustained manner and maintaining their particle size. Most importantly, polymeric nanoparticles of a biocompatible and biodegradable nature are of essential interest for target-specific drug delivery [38]. To date, limited numbers of polymers have received regulatory approval for use in clinics. Cost-effectiveness is another barrier for the polymeric nanoparticles which limits their wide spread application [7]. Lipids have been put forward as an alternative carrier to surmount the limitations of polymerics during the formulation of lipophilic pharmaceuticals. Contrasting with the polymeric nanoparticles, lipid nanoparticles such as solid lipid nanoparticles (SLNs) are gaining considerable attention as a worldwide drug delivery system for various clinical purposes [39].

SLNs are unique lipid-based biocompatible nanocarrier systems mainly constituting lipid or modified lipid (triglycerides, fatty acids, or waxes) nanostructures (10-1000 nm diameter size range). SLNs have a solid hydrophobic lipid core, in which both hydrophilic and lipophilic drugs can be dispersed [40,41]. They play a significant role in crossing the reticuloendothelial system (RES) of the BBB [42-44]. This colloidal nano-carrier was developed as a better substitute for polymeric nanoparticles and liposomes due to its solid lipid composition instead of an aqueous solution, to safeguard active-drug-counteracting biochemical degradation [45]. As they are formed of a physiological solid lipid emulsion system by maximally avoiding organic solvents, they display better biocompatibility and reduced systemic toxicity in comparison to polymeric nanoparticles [46]. SLNs containing drug also show a sustained release feature due to the use of solid lipids, modified drugs, and additive ingredients in a particular ratio, providing a particular physicochemical state with the longest diffusion pathway and controlled drug release [47-49]. Some study findings show that the pharmacokinetics, tissue distribution, and bioavailability of SLNs loaded with nitrendipine (antipsychotic drug) could be improved by administering nitrendipine SLN in rats [50]. SLNs require a low cost for raw materials and production, have excellent physico-chemical stability, and can be commercially sterilized and lyophilized in an affordable manner. These features make SLNs advantageous for production on a large industrial scale [43]. Furthermore, SLNs serve as an ideal drug delivery system with various important characteristic features such as maximum drug bioavailability upon administration, specific tissue targeting, controlled release kinetics, minimal immune response, the ability to deliver traditional pharmaceutical formulations and biomolecules, sufficient drug loading capacity, good patient compliance, and cost effectiveness, which might make it a better and unique system in comparison to polymeric nanoparticles and other formulations. Some of the advantages and disadvantages associated with SLNs are mentioned in Tables 1 and 2, with the utilities represented in the Figure 3. 
Table 1. Advantages of SLNs over polymeric nanoparticles.

- The lipid raw materials for SLNs are cheaper than the polymers (which also need regulatory approval for clinical use) [7]. So, it can be scaled up in a cost-effective manner due to cheaper synthetic approaches such as high pressure homogenization, etc. [51].

- SLNs can avoid organic solvent as per requirement during small scale or large-scale synthesis. Hence, these formulations are less toxic and biomimetic, biocompatible and biodegradable with less or no toxicity [51,52].

- $\quad$ SLNs escape RES bypassing liver and spleen filtration due to their unique physicochemical properties $[53,54]$. Furthermore, Lipids of SLNs are physiological and biodegradable, and hence have better biocompatibility. On the other hand, there is a chance polymeric nanoparticles accumulate in the liver, spleen etc. [55].

- $\quad$ Encapsulated drugs are more stable within SLN in comparison to the polymeric nanoparticle, so prolonged release profile even for months to years. Comparing with polymeric nanoparticles, SLNs prohibit leakage and protect the active drug component from degradation (photochemical, oxidative, and chemical degradation) by immobilizing within and resulting a stable formulation $[44,56]$.

- $\quad$ SLNs can encapsulate both hydrophilic and lipophilic drugs $[41,57,58]$.

- The bioavailability of hydrophobic drugs is improved when they are in SLNs formulation in comparison to polymeric nanoparticles due to the physiological stability of the lipids [59].

- When SLNs are conjugated with ligands, the drug targeting capability is improved $[60,61]$.

- $\quad$ Provide opportunities for targeted and controlled release of drug $[60,62,63]$.

Table 2. Disadvantages of SLNs.

- $\quad$ Poor drug loading due to limited space in the lipid matrix [64-67].

- Drug interaction with lipid matrix is very common, sometimes results in failure of desired SLNs production.

- During storage of SLNs, there may be chances of drug expulsion following polymeric transition [68,69].

- $\quad$ Relatively high-water content is not favorable condition for SLNs formulation from various points of view.

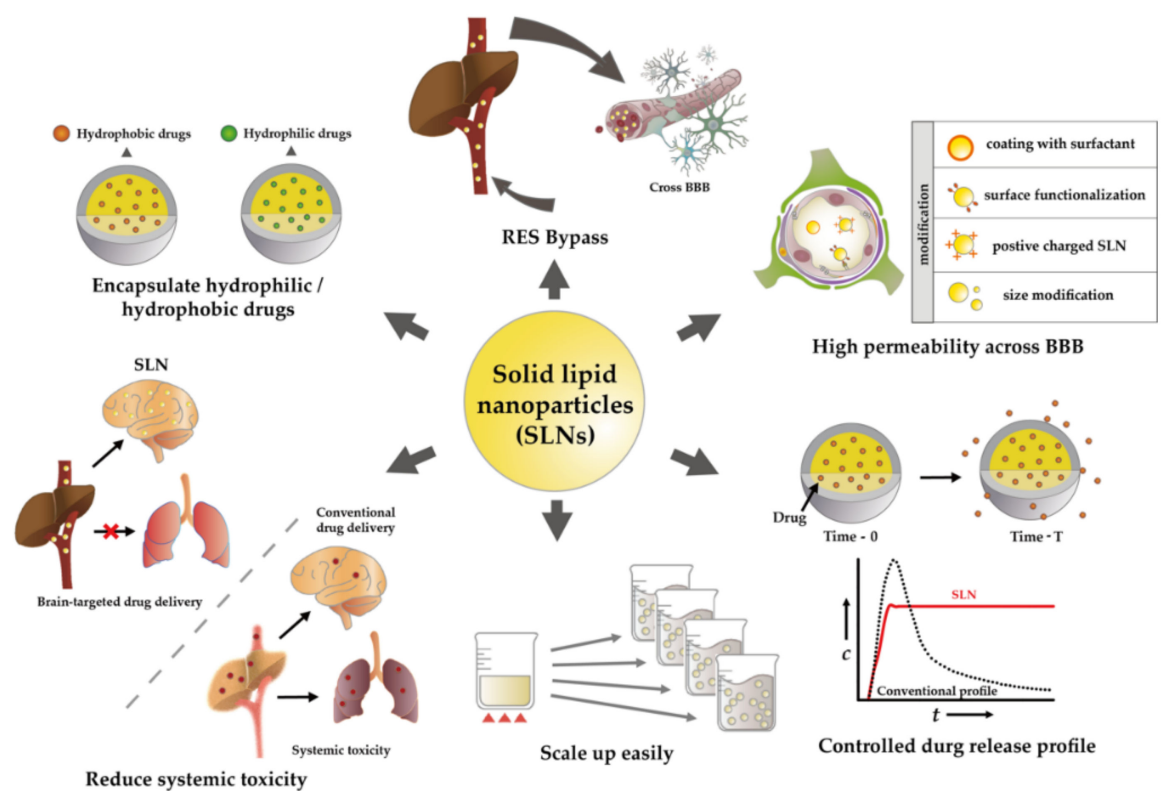

Figure 3. Highlighting the utilities of SLNs and their modifications such as: encapsulation of hydrophilic and lipophilic drugs, capable to cross the BBB for target specific drug delivery due to their unique physicochemical nature, can bypass RES system, reduce systemic toxicity, sustained or controlled drug release in a time dependent manner, and can be scaled up in a cost-effective way. 


\subsection{Drug Stabilization by SLN}

There are various drug formulations that, despite their ability to cross the BBB, show poor plasma stability, rapid clearance, and a short half-life, resulting in poor in vivo efficacy [70]. SLNs are one of the colloidal nanoformulations that can overcome the drug stability issues. SLNs' drug delivery design could improve the drug-loading capacity, drug stability, and bioavailability after crossing the BBB, maintaining the drug plasma concentration with less possible toxicity. For example, the anticancer drug camptothecin can cross the BBB and be used in glioblastoma therapy [71,72], although it cannot be used in clinical protocols due to its poor stability. However, the formulation has been used to stabilize the physiological $\mathrm{pH}$ and further stabilize size, charge, and pharmacokinetics using SLN modifications, showing better brain targeting efficacy [49,73-75].

\subsection{Enhanced Bioavailability of Drugs by SLN}

When certain lipophilic oral formulations for the treatment of neurological disorders suffer from poor bioavailability due to the first pass metabolism, these can be improved by encapsulation in SLN. The permeability of the drug molecules to the brain site can be improved by BBB-active drug efflux transporters based on the efflux mechanism. Manjunath and Venkateswarlu [76] tried to improve the bioavailability of the antipsychotic drugs clozapine and nitrendipine through their various SLN formulations, using PEG and Tween 80. 5-fluoro-2'-deoxyuridine (FUdR) to the brain, $3^{\prime}, 5^{\prime}$-dioctanoyl-5-fluoro-2'-deoxyuridine (DO-FUdR) incorporated into solid lipid nanoparticles (DO-FUdR-SLN), has shown good brain-targeting efficacy for CNS disorders, shown in the studies by Wang et al. [77]. The mechanism behind the enhanced drug bioavailability could be explained by: (1) surface modification of the SLN with Pluronic F-68, resulting in a steric hindrance effect, which would further decrease the adsorption of opsonin onto SLN in the plasma; hence, RES uptake can be reduced prolonging the retention time in plasma; (2) higher concentration gradient at the brain capillary due to higher SLN load, resulting in enhanced transport across the brain endothelium followed by endocytosis and drug release from SLN. Another study showed that the plasma half-life of the drug noscapine was enhanced by surface PEGylation, which could escape RES uptake [78].

\subsection{Enhanced BBB Permeability of Drugs by SLN}

SLN and their modifications are considerably better carrier system, which can encapsulate a broad range of drug molecules to deliver the drugs in a safe and effective manner. The anticancer drug doxorubicin (a hydrophilic drug) cannot cross the BBB, and shows acute toxicity and cardiomyopathy, leading to severe issues, which sometimes limits its use in clinical context. These shortcomings can be avoided if it can reach the target site. A study showed doxorubicin being incorporated in SLN prepared from a warm oil-in-water microemulsion containing stearic acid as an internal phase, with Epikuron 200 as a surfactant and taurocholate sodium salt as a cosurfactant. SLN-modified doxorubicin upon i.v. administration to rats showed lower drug concentration in the liver, heart, and kidneys, while a higher concentration was shown in the brain due to RES escaping, in comparison to free doxorubicin [79]. In another study, the presence of a stealth agent with SLN loaded with doxorubicin was shown to increase the plasma circulation of drugs and drug concentration in the rat brain after i.v. administration [57]. The study on riluzole (a drug for amyotrophic lateral sclerosis) showed that the SLN formulation results in better drug delivery to the brain [80]. The SLN formulation of paclitaxel (anticancer drug) stabilized with Brij 78 has shown better drug distribution in the brain in comparison to naïve drug, probably followed by P-gp-efflux-mediated brain drug delivery [81].

It is necessary to understand the different pathways through which the biological and pharmaceutical active components can cross the BBB (Figure 4). The detailed transportation mechanisms of each pathway are briefly described to obtain a general idea of how the active pharmaceutical components, with the help of a carrier system can cross the BBB to reach the brain. Although many strategies have been developed to nonspecifically disrupt 
the $\mathrm{BBB}$, allowing the pharmaceutical agents to enter into the brain, these may also allow circulating toxins enter the brain from the blood, causing severe neuro toxicity. There is a need for an ideal and safe approach by which we can improve the brain permeability of the drugs in a target-specific and sustained-release manner, without disrupting the BBB. Recent SLNs, and the modifications in drug delivery for the treatment of neurological disorders, are very promising biomaterials in the context of BBB-targeted drug delivery.

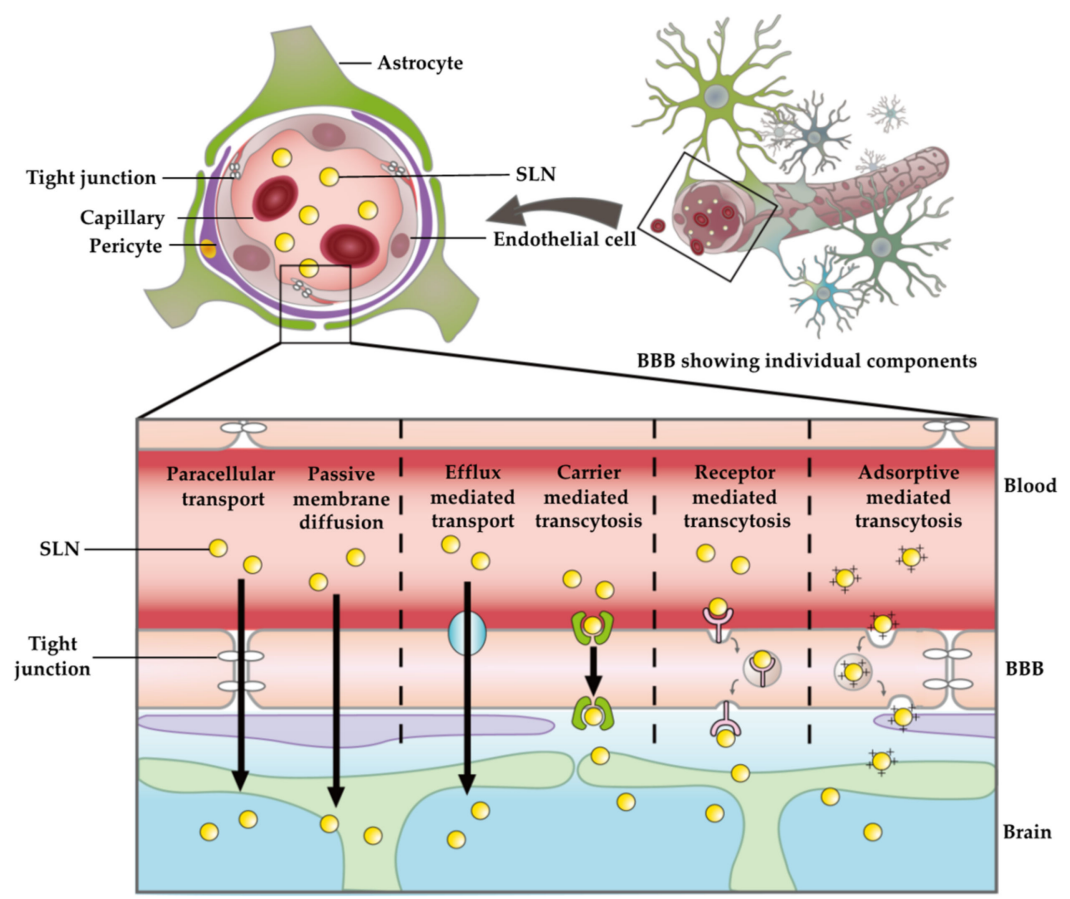

Figure 4. BBB showing individual components and how the drug loaded SLNs can cross the BBB by different physiological mechanisms such as: Paracellular pathway and passive transmembrane diffusion; Protein mediated transport; Receptor-mediated transcytosis (RMT); and Adsorptivemediated transcytosis (AMT).

(1) Paracellular pathway and passive transmembrane diffusion

The tight junctions between the endothelial cells play a major role in the paracellular pathways, allowing only hydrophilic molecules to pass. There is an alternative transcellular pathway, which allows lipophilic small molecules, with a molecular weight lower than $400 \mathrm{Da}$, to undergo transmembrane diffusion in a non-saturable and non-competitive manner [82]. Besides this, the endothelial cells of the BBB also restrict active molecules from entering the brain by limiting pinocytic activity [83-85].

(2) Protein-mediated transport

Transporter proteins are unique proteins responsible for delivering brain specific molecules by carrier-mediated transport and efflux proteins. Those are present on the luminal and basolateral side of the endothelial cells. For example, organic cation and anion transporters, GLUT-1, and large neutral amino acid transporters (LAT), play an important role in the delivery of various biomolecules $[84,86,87]$ and their substrates in a size- and stereo-selective manner [88]. Pharmaceutical drug molecules and their modifications can also pass through the BBB using these efflux mediated proteins i.e., P-glycoproteins (P-gp or ABCB1, MDR1 gene product), breast cancer resistance proteins (BCRP/ABCG2), and the multidrug resistance-associated proteins (MRP1, 2, 4, and 5, ABCC) [84].

(3) Receptor-mediated transcytosis (RMT)

RMT-mediated transport is a specialized transport system by which endogenous molecules can cross the BBB for brain delivery by the activation of peripheral brain endothelial cells [89]. This process is one of the one of the most promising pathways for drug delivery through the BBB. The steps involved in this process are as follows: endocytosis, 
intracellular vesicular trafficking and exocytosis [90]. During this RMT process, active components bind to their specific receptors on the luminal side of the endothelial cells. Then the receptor-ligand complexes build up intracellular transport vesicles. The formed vesicles cross the cell to release the ligand to its basolateral side using exocytosis [91]. The major receptors involved in RMT are transferrin receptor (TfR), insulin and insulin like growth factor receptor, low-density lipoprotein receptor (LDLR), low-density lipoprotein -receptor-related protein 1 and 2 (LRP1 and LRP2), scavenger receptor class B type I (SR-B1), leptin receptor, albumin receptor [90,92], and lactoferrin receptor [88,91]. The endocytic vesicles, which play a major role in this RMT, are clathrin-coated pits, caveolae, and macropinocytosis vesicles. Clathrin-coated pits are involved in most of the internalization processes that are mediated by receptors such as TfR or insulin receptors [89,90]. Hence, RMT is dependent on the internalization pathway (clathrin-mediated or caveolae) and the type of ligand binding to the receptors [89].

(4) Adsorptive-mediated transcytosis (AMT)

AMT is another important BBB-crossing pathway, without the involvement of specific plasma-membrane receptors. Hence the binding affinity of AMT is low, but the binding ability is high, with the same level of transcytosis efficiency as RMT [93,94]. The basic mechanism of AMT is based on the electrostatic interaction between the charged molecule, such as the positively charged protein and negatively charged luminal membrane of the brain endothelial cells $[95,96]$.

\section{Methods to Improve SLNs for Brain Drug Delivery}

There are various characteristic features which can be modified to improve the quality of the SLNs. For example, the SLNs loaded with drugs such as paclitaxel, vinblastine, camptothecin, etoposide, and cyclosporine (hydrophilic drugs) [41,49,73,97], due to their unique size, surface hydrophobicity, and surface mobility, can cross the BBB. However, those drugs may have shown limitations in their pharmacokinetics, resulting in poor pharmacological activity and therapeutic efficacy. The reason for this is their detection by the reticuloendothelial system (RES). Recent research has focused on how to improve the shortcomings associated with SLNs. Some of the approaches used are briefly described here (Figure 5).

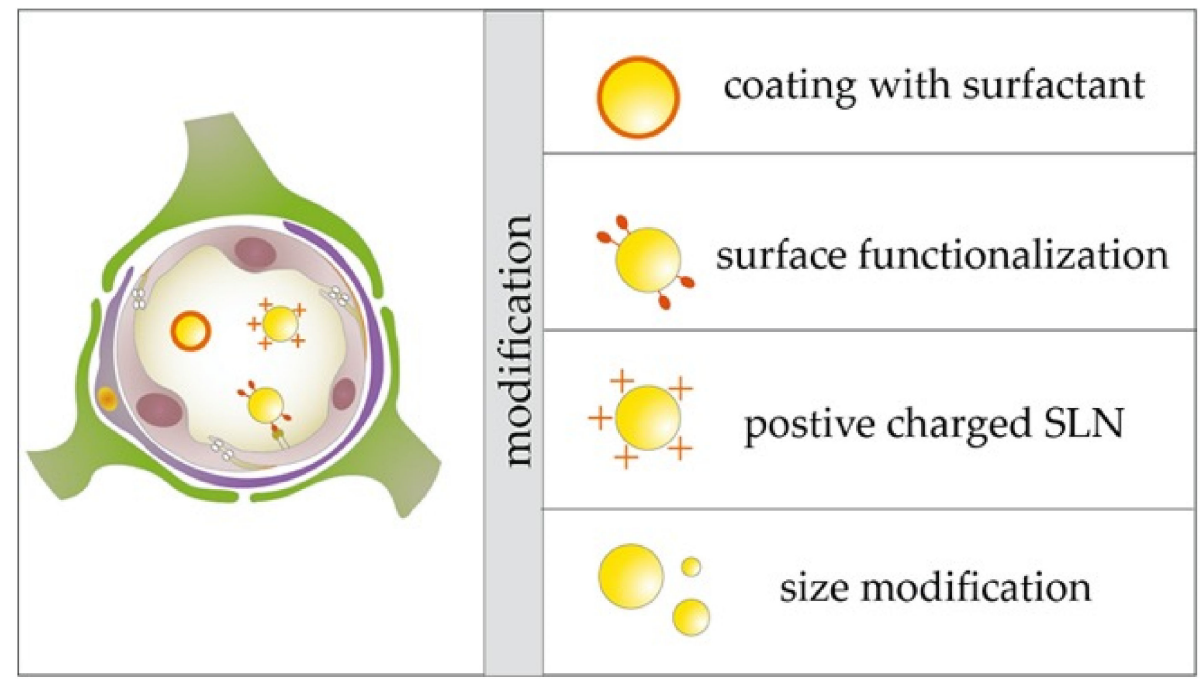

Figure 5. Methods to improve SLNs for brain drug delivery: coating with surfactant; surface functionalization; cationization; size modification.

(a) Particle size

Primarily particle size plays a major role in SLN efficacy during drug delivery, including in the therapeutic effect achieved and clearance from the body. The SLNs should be small enough or, if it is able to deform itself, it can avoid the splenic filtration process at the 
interendothelial cell slits (IES) [98,99]. The endothelial cells' slit width from 200 to $500 \mathrm{~nm}$ in width [98]. Hence, for the long-term circulation of the SLNs, they should be modified in such a way that the particle size does not exceed $200 \mathrm{~nm}$, so that they have an increased blood circulation time and the drug in contact with the BBB for the maximum time. This would lead to better brain drug delivery across the membrane. Sometimes if the size of the SLNs is larger, it can be deformed adequately to bypass IES filtration.

(b) Surface coating with hydrophilic polymers/surfactants

As RES-mediated active detection of colloidal nano-particles is very common, they can be cleared very quickly by the liver after the administration significantly reduces the half-life of the drug. Opsonization plays a major role in the entire process of drug clearance. RES recognition of the drug component should be prevented to increase its efficacy [100]. SLNs' modification, by coating them with a suitable surfactant or hydrophilic polymer, can bypass RES recognition and escape phagocytosis. If the hydrophobic nature of the nanoparticle containing the drug can be shielded, it will be sterically stabilized, thus avoiding opsonization, and further increasing the blood circulation time and hence the bioavailability [101]. For example, SLNs coated with a hydrophilic polymer polyethylene glycol (PEG) showed encouraging results due to their hydrophilicity, chain flexibility, electrical neutrality, and lack of functional groups, preventing them from undesired interactions with the biological components. Furthermore, when PEGs with a molecular weight of 2000 5000 are coated on SLNs, plasma protein adsorption can be reduced, and the thicker the PEG coat, the slower the RES clearance. This leads to better protection against first pass metabolism [41,102,103]. Other examples of hydrophilic compounds such as Brij 78, Poloxamer F68, and Brij 68, when coated with the paclitaxel-SLN formulation, show significantly increased drug bioavailability during i.v. injection in comparison to the plain drug [97]. Polysorbate (20, 60, 80)-coated SLNs showed an enhanced pharmacological effect through its easy transportation across the BBB via endocytosis triggered by apolipoprotein $[103,104]$. Another study reported that plain and stealth SLNs of doxorubicin and pristine can cross the BBB, without any functionalization. However, stealth SLNs showed better brain delivery of doxorubicin than pristine SLNs. Better results were found with increasing amounts of stealth agents, resulting in a longer blood circulation time in case of SLN-doxorubicin stealth [57,105-107].

(c) Use of ligands

Ligands increase the selectivity of SLN to make it a long-circulating carrier system and act as a homing device, which may specifically bind to surface receptors expressed by certain cell types, such as folic acid (over-expressed in cells of cancers with epithelial origin), low-density lipid (LDL) (B16 melanoma cell line shows higher expression of LDL receptors), and peptide receptors (such as somatostatin analogs, vasoactive intestinal peptide, gastrinrelated peptides, cholecystokinin, gluteinizing hormone releasing hormone), leading to increased selectivity $[108,109]$. Ligand-conjugated SLNs show a higher retention of drug molecules at the BBB [60]. Another study showed that colloidal particles coupled to sterically stabilized cationized albumin have a better interaction with brain endothelial cells and higher intracellular accumulation [110].

(d) Conjugation of SLN with arginine-glycine-aspartic (RGD)

Studies have showed that doxorubicin-SLN, when conjugated with RGD, increased in vitro antitumor efficacy and in vivo cytotoxicity in a target specific manner in comparison to non-targeted SLN [111]. RGD-conjugated SLNs can easily cross the BBB easily CNS drug delivery to the brain. One study showed that a SLN formulation of docetaxel functionalized with angiopep-2 can specifically bind to the LDL-receptor-related protein 1 (LRP1), which is overexpressed at the BBB, showing higher in vitro cytotoxicity and BBB permeability by receptor mediated endocytic processes [112]. Other studies are based on how to attaching a targeting ligand to an SLN, such as by linking a fatty acid of the NP to an amino group of the ligand [113], an amino group of a phospholipid to an acid group of the ligand [114], or an amino group of the chitosan coating to an acid group of the ligand [115]. These could lead to better brain drug delivery by the SLNs across BBB. 


\section{SLNs Different Models}

There are various patterns of SLN formulations according to the distribution of drug components within them. Different models of SLNs are as follows (Figure 6)

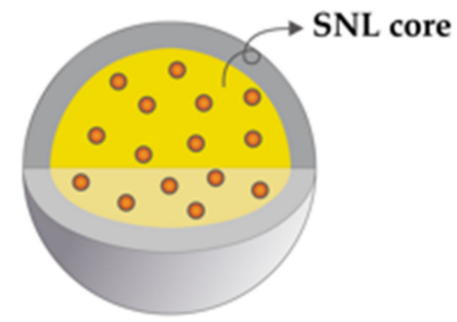

Drug-enriched core

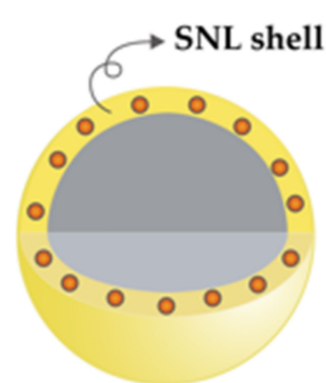

Drug-enriched shell

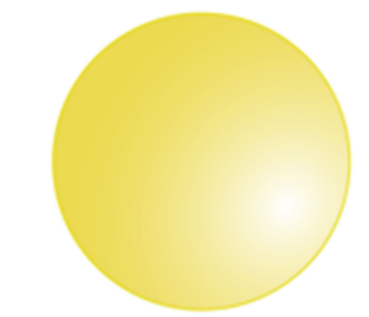

Solid lipid nanoparticles (SLN)

Figure 6. Different representative models for SLNs showing the drug distribution in the lipid core: Drug enriched core model, Drug enriched shell model, Homogenous matrix model.

\subsection{Drug-Enriched Shell Model}

In this model, the core of the SLN is drug free. The main active drug is distributed around the shell, as shown in Figure 6. A hot homogenization process is used for synthesis of this type of SLN. Hence, only the lipid content precipitates at the core at a recrystallisation temperature, leaving behind the drugs at the outer shell upon a decrease in the temperature of the obtained dispersion. The resulting solid lipid core is formed by recrystallization of the lipid independent of the drug component. In this types of SLN, the burst release of drug particles happens faster due to the large surface area of the outer layer where the drug is deposited [116,117]. However, the burst release can be controlled by replacing the smaller drugs with larger ones, such as lipid microparticles, and depending upon the properties of the surfactants used during formulation [118]. The use of surfactants at a lower concentration during the synthesis of SLNs could control the burst and, hence, prolong drug release.

\subsection{Drug-Enriched Core Model}

In this model of SLNs, the active drug is concentrated at the core with the outer lipid shell. This type of SLN is formed in several steps. The first liquification of drug in the lipid is carried out, leading to saturation solubility for the formation of drug lipid emulsion. Then, the mixture is cooled, and the active drug is concentrated at the center due to supersaturation. After further cooling of the dispersion, the lipid content is recrystallized as an outer layer containing the active drug at the core as shown in Figure 6. During this type of SLN formation, the drug precipitates prior to crystallization of the lipid; hence, it concentrates at the central core, surrounded by the lipid outer layer. In this type of SLN 
model, drug release is controlled by the nature of the lipid membrane, followed by Fick's law of diffusion [43].

\subsection{Homogeneous Matrix Model}

In this model, the active drug content is distributed in the lipid matrix of the SLNs Figure 6. This model is also known as the solid solution model. The drug may be present in dispersion or in amorphous clusters in the lipid. This type of SLN is prepared by a cold homogenization process, where the drug and the lipid interact. The drug has strong molecular interactions with the lipid to form this type of SLN. Generally, lipophilic drugs are encapsulated in the lipid matrix during the preparation of this type of model SLN, without the use of surfactants. The drug release profile is extended in this type of SLN formulations, due to the firm molecular dispersion of drug particles in the colloidal matrix [116].

\section{Synthesis Procedures for SLN}

The main component precursors required for SLN synthesis are emulsions, microemulsions, and micellar solutions [119], which include solid lipid (beeswax, stearic acid, cholesterol, caprylic/capric triglyceride, cetylpalmitate, glyceryl stearate (-mono, and -tri), glyceryl trilaurate, glyceryl trimyristate, glyceryl, behenate (compritol), glyceryl tripalmitate, hardened fat (witepsol E85, H5 and W35), monostearate monocitrate, solid paraffin, behenic acid triglycerides, partial glycerides, fatty acids, steroids, and waxes), surfactant (stabilizes the lipid dispersion, Ex. phosphatidyl choline, soy and egg lecithin, poloxamer, poloxamine, polysorbate 80), and water [120], along with cosurfactants (sodium dodecyl sulphate, tyloxopol, sodium oleate, taurocholate sodium salt, sodium glycocholate, butanol)preservatives (thiomersal), cryoprotectants (gelatin, glucose, mannose, maltose, lactose, sorbitol, mannitol, glycine, polyvinyl alcohol, polyvinyl pyrrolidone), and charge modifiers (dipalmitoyl phosphatidyl choline, stearylamine, dicetylphosphate, dimyristoyl phophatidyl glycerol) [121].

When administered, the biological efficacy of the drug-entrapped SLN depends upon its physicochemical properties, such as its size, shape and chemical nature. These formulations are amenable to change, depending on the requirement. Aiming to obtain variation in the nature, size, and shape of SLNs, many techniques have been developed over the years. Some of the major techniques used are mentioned here and all the procedures are shown in Table 3.

Table 3. Synthesis procedures for SLNs.

\begin{tabular}{|c|c|c|c|c|c|c|}
\hline Technique & Precursor & Temp. & $\begin{array}{l}\text { Particle Size } \\
\text { Formed }\end{array}$ & Advantage & Disadvantage & Reference \\
\hline $\begin{array}{l}\text { Coacervation } \\
\text { method }\end{array}$ & $\begin{array}{l}\text { Soap micellar } \\
\text { solution }\end{array}$ & $25^{\circ} \mathrm{C}$ & $200-1000 \mathrm{~nm}$ & $\begin{array}{c}\text { Drug can be } \\
\text { dissolved directly in } \\
\text { the micellar } \\
\text { solution allow an } \\
\text { advantageous drug } \\
\text { loading within SLN } \\
\text { for many drugs } \\
\text { including poorly } \\
\text { water-soluble drugs, } \\
\text { high encapsulation } \\
\text { yield, protection to } \\
\text { the bioactive } \\
\text { molecules }\end{array}$ & $\begin{array}{l}\text { Nonuniform sized } \\
\text { particle formation }\end{array}$ & [122-125] \\
\hline $\begin{array}{l}\text { Cryogenic } \\
\text { micronisation }\end{array}$ & $\begin{array}{l}\text { Supercritical fluid } \\
\text { emulsion/Drug } \\
\text { lipid matrix }\end{array}$ & $70{ }^{\circ} \mathrm{C}$ & $1-500 \mu \mathrm{m}$ & $\begin{array}{l}\text { Powdered SLNs are } \\
\text { directly formed }\end{array}$ & $\begin{array}{l}\text { Sometimes solvent } \\
\text { associated toxicity }\end{array}$ & [126] \\
\hline
\end{tabular}


Table 3. Cont.

\begin{tabular}{|c|c|c|c|c|c|c|}
\hline Technique & Precursor & Temp. & $\begin{array}{l}\text { Particle Size } \\
\text { Formed }\end{array}$ & Advantage & Disadvantage & Reference \\
\hline Electrospray & $\begin{array}{l}\text { Supercritical fluid } \\
\text { emulsion/Matrix } \\
\text { solution }\end{array}$ & $5-10{ }^{\circ} \mathrm{C}$ & $1 \mu \mathrm{m}$ & $\begin{array}{l}\text { Monodisperse } \\
\text { lipid-based } \\
\text { nano-and } \\
\text { microparticles } \\
\text { formation }\end{array}$ & $\begin{array}{l}\text { Variation in particle } \\
\text { size }\end{array}$ & {$[127,128]$} \\
\hline $\begin{array}{l}\text { Gas Anti-Solvent } \\
\text { (GAS) process }\end{array}$ & $\begin{array}{l}\text { Hydrophobic } \\
\text { materials }\end{array}$ & $25-55^{\circ} \mathrm{C}$ & 200-2000 nm & $\begin{array}{c}\text { Nanosized } \\
\text { hydrophobic } \\
\text { material formation }\end{array}$ & $\begin{array}{l}\text { Solvent system } \\
\text { incompatibility }\end{array}$ & [129] \\
\hline $\begin{array}{c}\text { Hot } \\
\text { homogenization }\end{array}$ & Emulsion & $5-10^{\circ} \mathrm{C}$ & $50-1000 \mathrm{~nm}$ & $\begin{array}{l}\text { On a large scale for } \\
\text { parenteral emulsion } \\
\text { preparation in a } \\
\text { nontoxic way }\end{array}$ & $\begin{array}{l}\text { Not suitable for } \\
\text { encapsulation of } \\
\text { hydrophilic and } \\
\text { thermosensitive } \\
\text { drugs, metal } \\
\text { contamination }\end{array}$ & {$[43,130,131]$} \\
\hline $\begin{array}{c}\text { Cold } \\
\text { homogenization }\end{array}$ & Emulsion & $0-4{ }^{\circ} \mathrm{C}$ & $50-100 \mu \mathrm{m}$ & $\begin{array}{l}\text { Homogenous drug } \\
\text { distribution in the } \\
\text { lipid matrix }\end{array}$ & $\begin{array}{l}\text { Larger particle sizes } \\
\text { and a broader size } \\
\text { distribution }\end{array}$ & {$[132,133]$} \\
\hline $\begin{array}{l}\text { Melt dispersion } \\
\text { technique }\end{array}$ & Emulsion & $90^{\circ} \mathrm{C}$ & $1-250 \mu \mathrm{m}$ & $\begin{array}{l}\text { Both hydrophilic } \\
\text { and lipophilic drugs } \\
\text { can be encapsulated } \\
\text { either from } \mathrm{O} / \mathrm{W} \text { or } \\
\text { multiple } \mathrm{W} / \mathrm{O} / \mathrm{W} \\
\text { emulsions }\end{array}$ & $\begin{array}{l}\text { Sometimes bigger } \\
\text { size microparticles } \\
\text { are formed }\end{array}$ & {$[134,135]$} \\
\hline $\begin{array}{c}\text { Membrane } \\
\text { contactor technique }\end{array}$ & $\begin{array}{l}\text { Supercritical fluid } \\
\text { emulsion/Lipid } \\
\text { and the drug }\end{array}$ & $-80^{\circ} \mathrm{C}$ & $100-200 \mathrm{~nm}$ & $\begin{array}{l}\text { Easy operation, } \\
\text { formation through a } \\
\text { membrane unit }\end{array}$ & $\begin{array}{l}\text { Bigger size particle } \\
\text { formation, } \\
\text { nonuniformity }\end{array}$ & {$[136,137]$} \\
\hline $\begin{array}{l}\text { Microemulsion } \\
\text { cooling technique }\end{array}$ & Microemulsion & $40-75^{\circ} \mathrm{C}$ & $50-300 \mathrm{~nm}$ & $\begin{array}{c}\text { Simple, } \\
\text { cost-effective, } \\
\text { ingredients are } \\
\text { potentially } \\
\text { biocompatible, } \\
\text { well-defined and } \\
\text { uniform solid } \\
\text { nanoparticle } \\
\text { formation, very } \\
\text { high entrapment } \\
\text { efficiencies of drugs } \\
\text { within SLN }\end{array}$ & $\begin{array}{l}\text { Use of a large } \\
\text { concentration of } \\
\text { surfactant and co- } \\
\text { surfactant necessary } \\
\text { for stabilizing nano } \\
\text { droplets, limited } \\
\text { solubilizing } \\
\text { capacity for } \\
\text { high-melting } \\
\text { substances. }\end{array}$ & [81,138-140] \\
\hline $\begin{array}{l}\text { Microemulsion } \\
\text { dilution technique }\end{array}$ & Microemulsion & $37-55^{\circ} \mathrm{C}$ & $50-800 \mathrm{~nm}$ & $\begin{array}{c}\text { Thermodynamically } \\
\text { optimized } \\
\text { structures; direct } \\
(\mathrm{O} / \mathrm{W}), \text { reversed } \\
\text { (W/O) and multiple } \\
\text { (W/O/W and } \\
\mathrm{O} / \mathrm{W} / \mathrm{O} \text { ) emulsions } \\
\text { and SLN can be } \\
\text { formed }\end{array}$ & $\begin{array}{l}\text { Bigger size particles } \\
\text { formed }\end{array}$ & [141-146] \\
\hline $\begin{array}{c}\text { Particles from } \\
\text { Gas-saturated Solu- } \\
\text { tions/Suspensions } \\
\text { (PGSS) }\end{array}$ & $\begin{array}{l}\text { Gas saturated } \\
\text { solution and } \\
\text { suspension/Lipid } \\
\text { and the drug }\end{array}$ & $31^{\circ} \mathrm{C}$ & $0.2-20 \mu \mathrm{m}$ & $\begin{array}{l}\text { Formation of solid } \\
\text { particles or droplets, } \\
\mathrm{CO}_{2} \text { solubility of } \\
\text { the compound is } \\
\text { not necessary, }\end{array}$ & $\begin{array}{l}\text { Bigger size particle, } \\
\text { complex operating } \\
\text { system }\end{array}$ & [147-149] \\
\hline PIT method & Emulsion & $5-10^{\circ} \mathrm{C}$ & $30-100 \mathrm{~nm}$ & $\begin{array}{c}\text { Nano W/O } \\
\text { emulsion and SLN } \\
\text { can be formed by } \\
\text { phase inversion } \\
\text { method }\end{array}$ & $\begin{array}{l}\text { Sometimes not } \\
\text { suitable for } \\
\text { thermosensitive } \\
\text { substances }\end{array}$ & [150-152] \\
\hline $\begin{array}{l}\text { Rapid Expansion of } \\
\text { Supercritical } \\
\text { Solutions } \\
\text { (RESS)/supercritical } \\
\text { fluid nucleation } \\
\text { (SFN) }\end{array}$ & $\begin{array}{l}\text { Drug and coating } \\
\text { material }\end{array}$ & $35-45^{\circ} \mathrm{C}$ & $200-2000 \mathrm{~nm}$ & $\begin{array}{l}\text { Used for lipid } \\
\text { coated microparticle } \\
\text { formation }\end{array}$ & $\begin{array}{l}\text { Low solubility of } \\
\text { the compounds }\end{array}$ & {$[129,153]$} \\
\hline
\end{tabular}


Table 3. Cont.

\begin{tabular}{|c|c|c|c|c|c|c|}
\hline Technique & Precursor & Temp. & $\begin{array}{l}\text { Particle Size } \\
\text { Formed }\end{array}$ & Advantage & Disadvantage & Reference \\
\hline $\begin{array}{l}\text { Solvent diffusion } \\
\text { from emulsions }\end{array}$ & $\begin{array}{l}\text { Organic solvent } \\
\text { emulsion }\end{array}$ & $40-50^{\circ} \mathrm{C}$ & $100-2000 \mathrm{~nm}$ & $\begin{array}{c}\text { Lipophilic and } \\
\text { hydrophilic drugs } \\
\text { can be encapsulated }\end{array}$ & Sometimes toxic & [154-157] \\
\hline $\begin{array}{l}\text { Solvent } \\
\text { evaporation from } \\
\text { emulsions }\end{array}$ & $\begin{array}{l}\text { Organic solvent } \\
\text { emulsion }\end{array}$ & $25^{\circ} \mathrm{C}$ & $30-500 \mathrm{~nm}$ & $\begin{array}{l}\text { Both hydrophilic } \\
\text { and lipophilic drugs } \\
\text { can be encapsulated } \\
\text { in SLN }\end{array}$ & Not biocompatible & [154-157] \\
\hline Solvent injection & $\begin{array}{l}\text { Organic solvent } \\
\text { emulsion/Lipid } \\
\text { and the drug }\end{array}$ & $25^{\circ} \mathrm{C}$ & $100-500 \mathrm{~nm}$ & Easy operation & $\begin{array}{l}\text { Sometimes toxic } \\
\text { according to the } \\
\text { nature of the } \\
\text { solvents used, } \\
\text { Particle size } \\
\text { non-uniformity }\end{array}$ & {$[158,159]$} \\
\hline Spray congealing & $\begin{array}{l}\text { Supercritical fluid } \\
\text { emulsion/Lipid } \\
\text { and the drug }\end{array}$ & $5-10{ }^{\circ} \mathrm{C}$ & $50-2000 \mu \mathrm{m}$ & $\begin{array}{c}\text { SLN-solid } \\
\text { dispersion from } \\
\text { poorly } \\
\text { water-soluble drugs }\end{array}$ & $\begin{array}{c}\text { Bigger size SLN, } \\
\text { may not be suitable } \\
\text { for thermosensitive } \\
\text { drugs }\end{array}$ & {$[160,161]$} \\
\hline Spray-drying & $\begin{array}{l}\text { Supercritical fluid } \\
\text { emulsion/Liquid } \\
\text { feed (emulsion, } \\
\text { liposome) }\end{array}$ & $25^{\circ} \mathrm{C}$ & $0.3-10 \mu \mathrm{m}$ & $\begin{array}{l}\text { Ease of parameter } \\
\text { control for desired } \\
\text { SLN formulation }\end{array}$ & $\begin{array}{l}\text { Drug degradation } \\
\text { sometimes occurs, } \\
\text { nonuniform shape } \\
\text { particle formation }\end{array}$ & [162-164] \\
\hline $\begin{array}{l}\text { Supercritical Fluid } \\
\text { Extraction of } \\
\text { Emulsions (SFEE). }\end{array}$ & $\begin{array}{l}\text { Supercritical fluid } \\
\text { emulsion/Lipid } \\
\text { and the drug }\end{array}$ & $5-10{ }^{\circ} \mathrm{C}$ & $20-90 \mathrm{~nm}$ & $\begin{array}{c}\text { Lipid } \\
\text { nanosuspensions } \\
\text { formation, uniform } \\
\text { sized particle }\end{array}$ & $\begin{array}{c}\text { Solvent, } \\
\text { temperature and } \\
\text { pressure conditions } \\
\text { affect the SLN } \\
\text { particle properties }\end{array}$ & {$[165,166]$} \\
\hline $\begin{array}{l}\text { High shear/ high } \\
\text { speed/ ultrasound } \\
\text { homogenization }\end{array}$ & & $5-10{ }^{\circ} \mathrm{C}$ & $50-1000 \mathrm{~nm}$ & $\begin{array}{l}\text { Wide spread } \\
\text { process, easy to } \\
\text { handle }\end{array}$ & $\begin{array}{c}\text { Metal } \\
\text { contamination, } \\
\text { bigger size particle } \\
\text { formation }\end{array}$ & [120,167-169] \\
\hline
\end{tabular}

\subsection{High-Shear/High-Speed/-Ultrasonication Homogenization}

High-shear homogenization was traditionally used for SLN [170] suspension. Melt emulsification produces SLNs using the high-speed/high shear homogenization method $[169,171]$. The nature of the SLNs (i.e., size, zeta potential, poly-dispersity index) produced depends upon various process parameters, such as time, stirring speed, and cooling condition. (Olbrich et al.). Ex-Witepsol W35 SLN dispersions [172] are produced by this method. Microparticle formation may be a limitation during this procedure affecting the dispersion quality. SLNs can also be synthesized by ultrasonication $[120,170,173]$ (Figure 7) in an easily assessable way, to overcome the limitations of high-shear homogenization. The advantage of this process is that it does not need any sophisticated equipment. Its limitation may be the physical instability of the particles up on storage, and metal contamination. Hence, a combined process with a high temperature and high speed, along with ultrasonication, may ensure the production of quality SLNs [174]. 


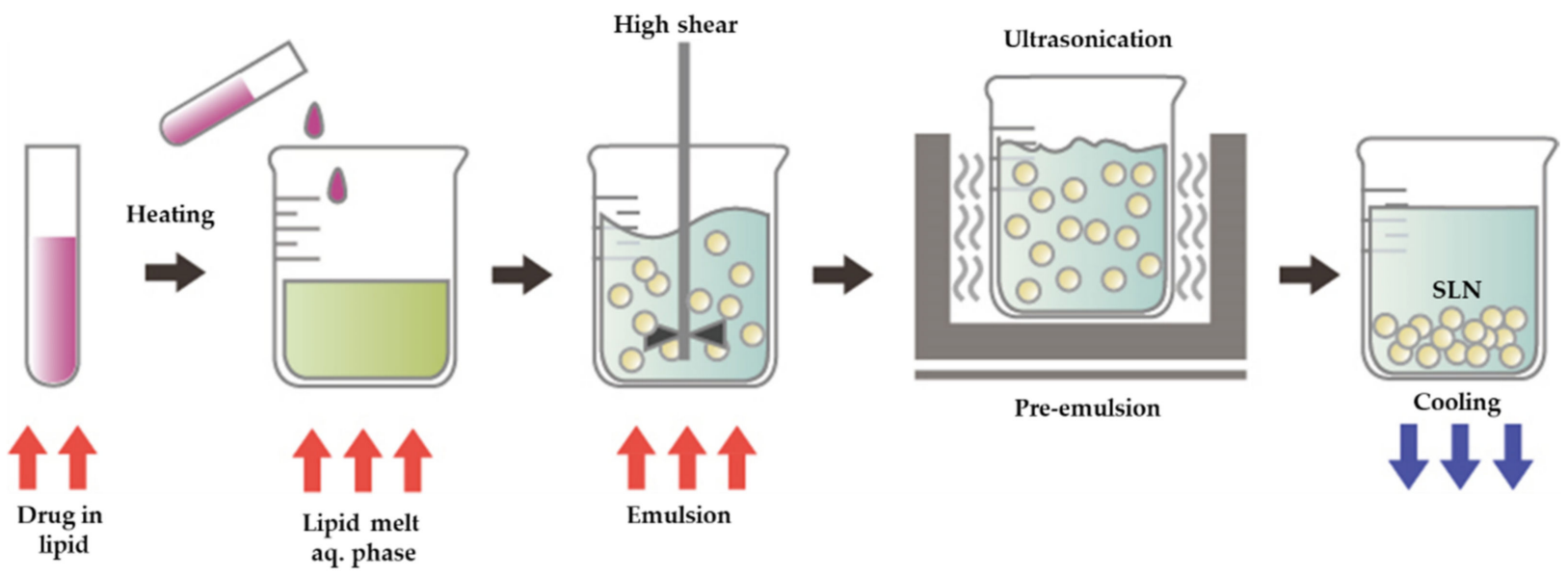

Figure 7. The procedure of high shear/high speed/ultrasonication homogenization.

\subsection{Hot Homogenization}

Hot homogenization is the process (Figure 8) of emulsion formation from lipids where, a high temperature (above melting point) is required to homogenize the lipid. During this process, a pre-emulsion (containing the drug and lipid mixture) is melted to obtain the aqueous emulsion by high-shear mixer. Then, this is cooled to obtain crystalized lipid SLNs as the final product. The final SLNs' emulsion size and properties are dependent on the pre-emulsion contents and surfactant used. Microparticles are usually obtained during this process. However, at higher processing temperatures lower particle sizes are obtained, due to the reduced viscosity of the lipid phase at high temperatures [175]. High temperatures may be responsible for degradation of the drug and carrier substance, forming a limitation of this process [176].

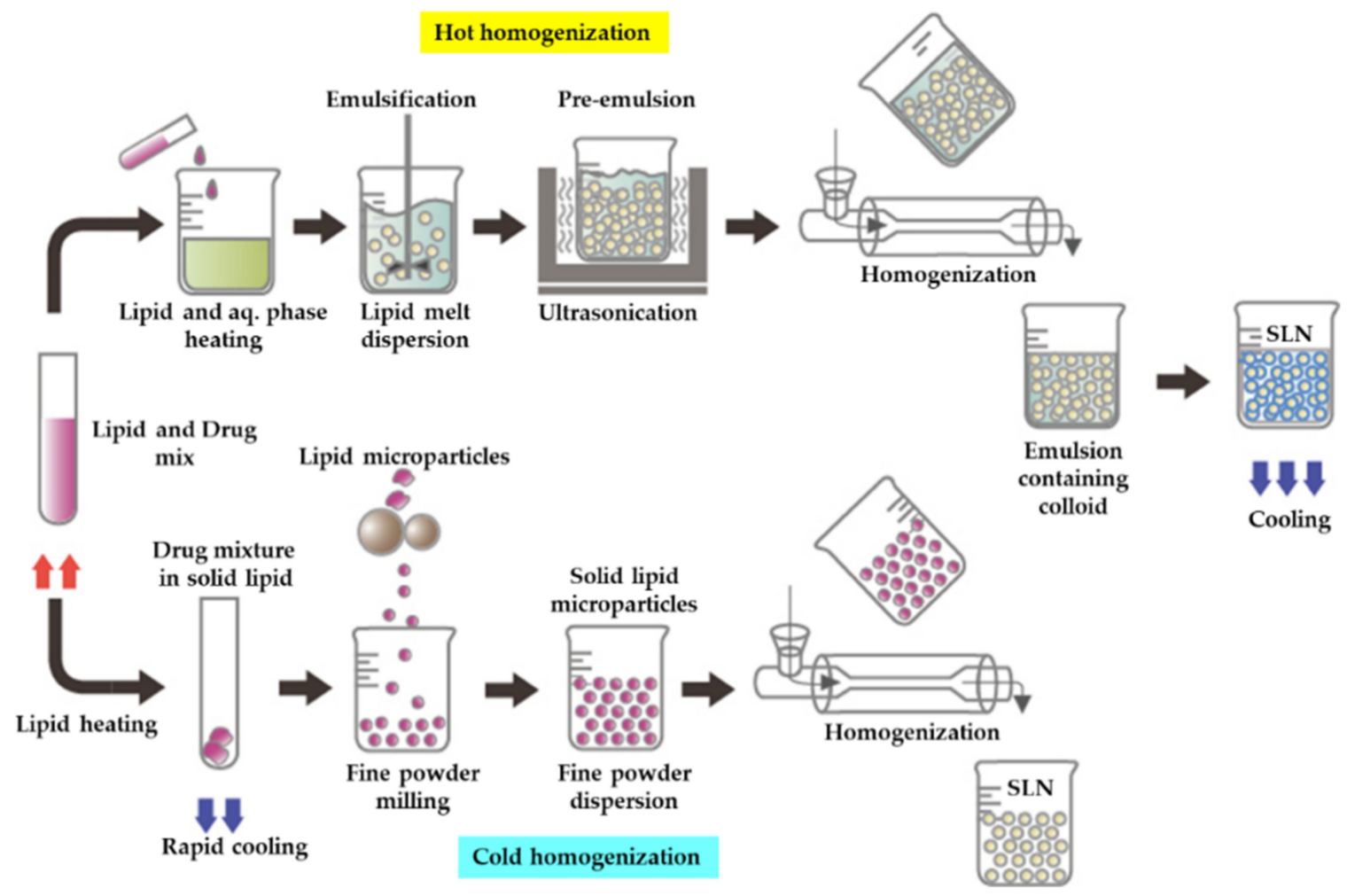

Figure 8. The procedure of hot homogenization and cold homogenization. 


\subsection{Cold Homogenization}

Cold homogenization (Figure 8) includes the cooling (dry ice or liquid nitrogen) of drugs and lipids to form a suspension at elevated pressure at a regulated temperature [176]. Then the solid drug-lipid core is ground by ball/mortar milling to obtain lipid microparticles of the size range between $50-100 \mathrm{~mm}$. Sudden cooling may be a limitation of this process making the lipid fragile. However, it is a better option than hot homogenization, producing a broad range of SLN sizes [177].

\subsection{SLN Prepared by Solvent Emulsification/Evaporation}

During this process (Figure 9), a uniform lipid solution is prepared with a suitable organic solvent. Then water is added to this lipid solution to form an $\mathrm{o} / \mathrm{w}$ coarse emulsion using a high-speed homogenizer. Then, a high-pressure homogenizer is used to obtain nano-emulsion of the solution mixture containing globules of a larger size. Then, from the nano-emulsion, the SLNs can be separated by continuous stirring overnight and separation of the organic solvent. After this, the lipid precipitate recovering in an aqueous solution is filtered to obtain the final SLNs, with a particle size of around $25 \mathrm{~nm}$ [178].
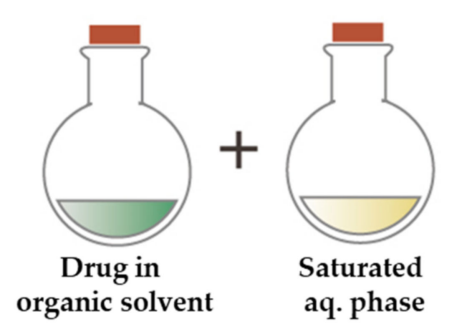
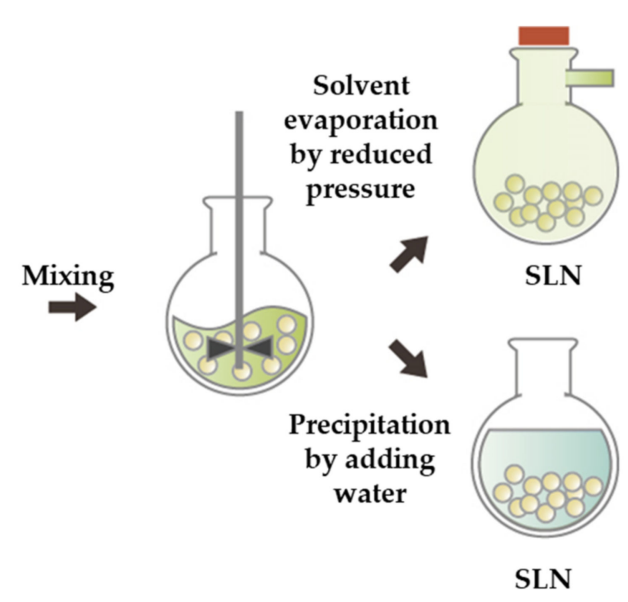

Figure 9. The procedure of emulsification solvent diffusion/evaporation.

\subsection{Micro-Emulsion-Based SLN Preparations}

During this process (Figure 10), indirect heating is used to prepare the solid lipid melts. The aqueous solution of the solid lipid melts is then prepared using water, surfactant, and a co-surfactant. If these aqueous solutions are mixed with the lipid melt by continuous stirring, microemulsions are formed spontaneously. This process was first used by Gasco and co-workers for SLN formation based on the dilution of microemulsions [144]. The particle size depends on the solvents, e.g., larger-sized SLNs are obtained with more lipophilic solvents, whereas the use of hydrophilic co-solvents results in a small and uniform particle formation [179].

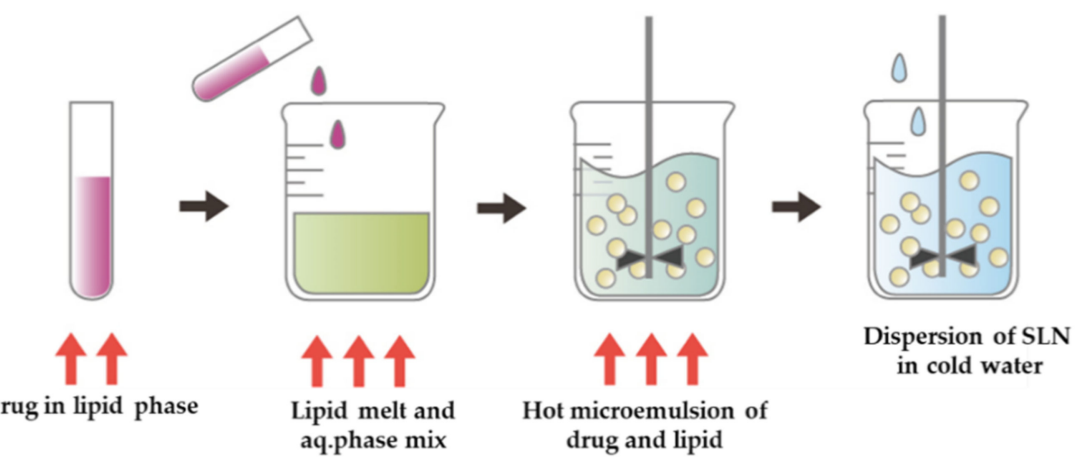

Figure 10. The procedure of microemulsion technique. 


\subsection{SLN Preparation by Using Supercritical Fluid}

This process (Figure 11) is an advanced technique compared to the conventional methods where SLNs can be produced by particles from gas saturated solutions (GSS), with a tuning pressure and temperature based on solvent power, liquid-like densities, and gas-like transport properties. Lipid material is first melted by GSS. Then under ambient pressure, the lipid melt along with GSS will be dissolved in the super-critical fluid (SCF). This saturated solution mixture is then sprayed through an atomizer, where the SCF escapes rapidly, leaving fine dry SLNs. The main advantage of this technique is that it is a solvent-less process $[180,181]$, where the powder form of the SLN in a nano-size range is formed. Ex-SLN can be prepared in the presence of carbon dioxide $(99.99 \%)$, then used as a solvent during the rapid expansion of the supercritical carbon dioxide solutions (RESS) method [182].

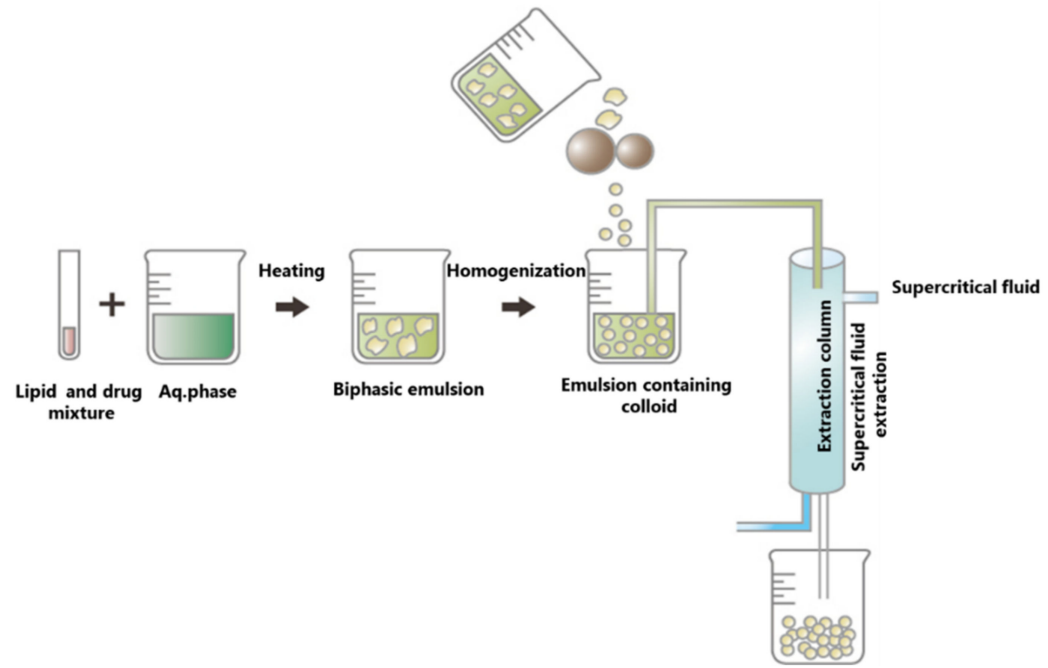

Figure 11. The procedure of supercritical fluid technique.

\subsection{Spray Drying Method}

This method is rarely used at present. This process is an optional and cheaper lyophilization method if there is a need to transform an aqueous SLN suspension into a drug product (Figure 12). Particle aggregation is the main limitation of this process, which occurs due to the high temperature, shear forces and partial melting of the particle [129]. This method is further restricted to lipids with a melting point above $70{ }^{\circ} \mathrm{C}[183,184]$.

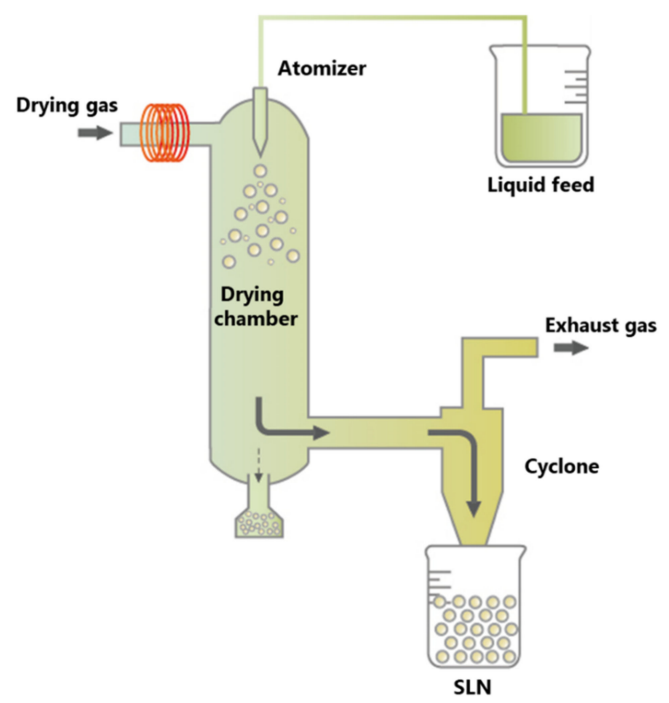

Figure 12. The procedure of spray drying technique. 


\subsection{Double Emulsion Method}

Generally, hydrophilic drugs can be loaded to SLNs by this double emulsion method (Figure 13), where solvent emulsification-evaporation is the core mechanism [185]. During this process, the drug is encapsulated with a stabilizing agent to prevent drug partitioning to the aqueous phase of $\mathrm{w} / \mathrm{o} / \mathrm{w}$ double emulsion. The double emulsion technique is the most frequently used technique. However, it produces larger-sized SLNs, which may need surface modification during synthesis [186].
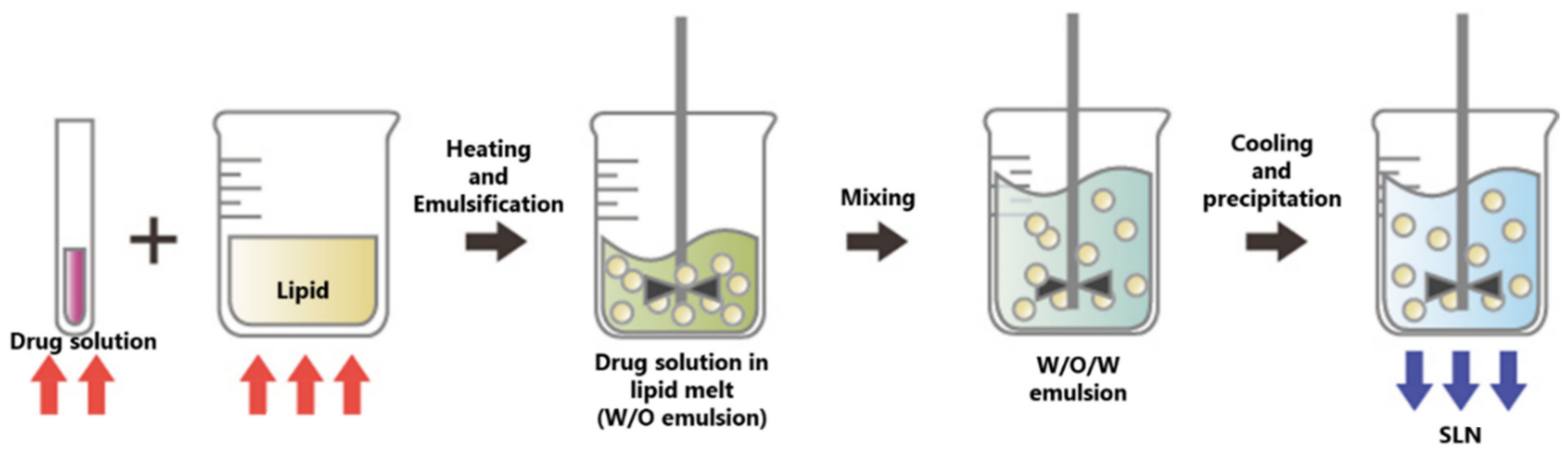

Figure 13. The procedure of double emulsion technique.

\section{Applications of SLNs in CNS Disorders}

As the maximum of the pharmaceutical formulations for the treatment of CNS-related disorders cannot cross the BBB, there are limited therapeutic benefits. Accordingly, SLNs are one of the best rational biomedical approaches as they can significantly overcome BBB-associated limitations, leading to successful drug delivery. Recent research on SLNs as a carrier system have aimed to target the brain, delivering drugs across the BBB. SLNs, with its advanced features, is a new smart drug delivery system for the treatment of neurological disorders, with ideal characteristic features such a nanodiameter range, site-specific targeted delivery (via receptor-mediated transcytosis across brain capillary endothelial cells), physical stability, ability to escape the reticulo-endothelial system, extended blood circulation time, sustained release, and nontoxic, biodegradable, and biocompatible qualities. From an economic perspective, SLN manufacture is scalable and cost-effective [187].

Research has shown that there is a comparatively high accumulation and targeting potential for drug-loaded SLN carriers in brain than in other organs during intravenous administration [49]. SLNs, as unique delivery systems encapsulating active pharmaceuticals for the treatment of CNS disorders, can be delivered via oral, inhalational, and parenteral routes [188] to reach the neuronal sites. Thereafter, SLNs intervene in pathological signaling pathways as well as in the metabolism, correcting the neuropathologies. There are several prospective applications of SLNs loaded with drugs to treat CNS disorders. In recent years, many research studies have been published, and are ongoing, which are relevant to the use of drug-loaded SLNs for the treatment of various CNS disorders, including AD, PD, $\mathrm{HD}$, multiple sclerosis, brain tumors and cancer, epilepsy, ischemic stroke, and certain neurodegenerative disorders (Figure 14). Some of these are provided in Table 4. 


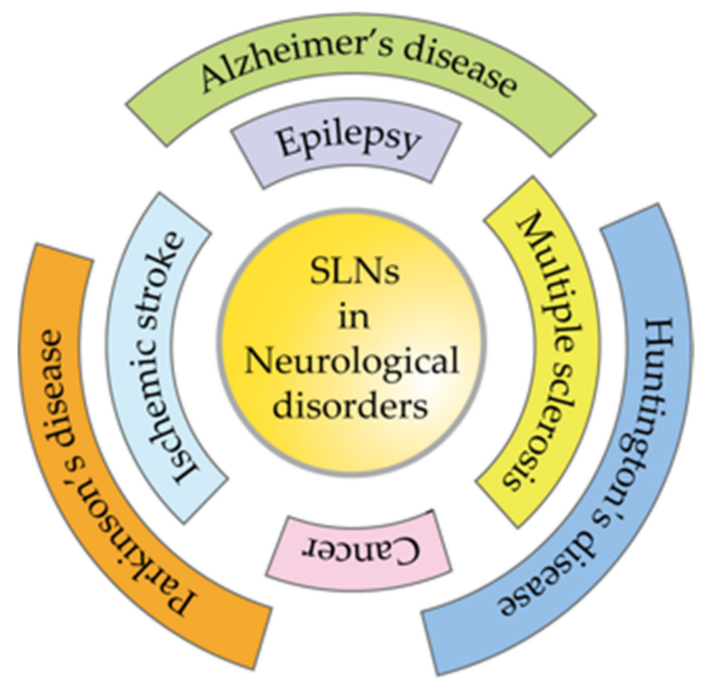

Figure 14. Representation of SLNs applications in CNS in various types of Neurodegenerative disorders.

Table 4. Applications of SLNs in neurological disorders.

\begin{tabular}{|c|c|c|c|c|}
\hline CNS Disorder & SLNs & Function & $\begin{array}{c}\text { Study } \\
\text { Performed }\end{array}$ & Reference \\
\hline \multirow[t]{7}{*}{$\begin{array}{l}\text { Alzheimer's } \\
\text { Disease }\end{array}$} & $\begin{array}{l}\text { Nicotinamide loaded SLN } \\
\text { functionalized with } \\
\text { polysorbate } 80 \text { (S80), } \\
\text { phosphatidylserine (PS) or } \\
\text { phosphatidic acid (PA) }\end{array}$ & $\begin{array}{l}\text { Histone deacetylase } \\
\text { (HDAC) inhibitor }\end{array}$ & In vivo & [189] \\
\hline & & $\begin{array}{l}\text { Superior nasal } \\
\text { mucoadhesion and } \\
\text { permeation, extended drug } \\
\text { release, reducing oxidative } \\
\text { stress, superior } \\
\text { pharmacodynamic } \\
\text { performance }\end{array}$ & $\begin{array}{l}\text { Via nose-to-brain in } \\
\text { goat ex vivo, in vivo, } \\
\text { and preclinical study }\end{array}$ & [190] \\
\hline & SLNs sesamol & $\begin{array}{l}\text { Reduced } \\
\text { acetylcholinesterase } \\
\text { activity, attenuated } \\
\text { oxidative-nitrergic stress } \\
\text { and inflammatory } \\
\text { cytokines }\end{array}$ & In vivo study & [191] \\
\hline & Galantamine loaded SLN & $\begin{array}{l}\text { Enhanced bioavailability } \\
\text { and improved drug } \\
\text { delivery }\end{array}$ & In vitro & [192] \\
\hline & Quercetin-loaded SLN & Reverse neurodegeneration & In vivo & [193] \\
\hline & Piperine loaded SLN & $\begin{array}{l}\text { Overcome poor water } \\
\text { solubility and BBB } \\
\text { permeation }\end{array}$ & In vivo & [194] \\
\hline & $\begin{array}{l}\text { SLN carrying phosphatidic } \\
\text { acid or cardiolipin }\end{array}$ & $\begin{array}{l}\text { High affinity for the } A \beta \\
\text { peptide }\end{array}$ & In vitro & [195] \\
\hline
\end{tabular}


Table 4. Cont.

\begin{tabular}{|c|c|c|c|c|}
\hline CNS Disorder & SLNs & Function & $\begin{array}{c}\text { Study } \\
\text { Performed }\end{array}$ & Reference \\
\hline & Ferulic acid loaded SLN & $\begin{array}{l}\text { Overcome permeability } \\
\text { issues and reduce oxidative } \\
\text { stress in } A \beta \text {-treated cells }\end{array}$ & In vitro & [196] \\
\hline & Epigallocatechin3-gallate & $\begin{array}{l}\text { Improving oral } \\
\text { bioavailability and } \\
\text { preventing brain } A \beta \\
\text { plaque formation }\end{array}$ & In vivo & {$[197]$} \\
\hline & Curcumin loaded SLN & $\begin{array}{l}\text { To completely reverse } \\
\text { brain alterations induced } \\
\text { by aluminum }\end{array}$ & In vivo & {$[198]$} \\
\hline \multirow[t]{5}{*}{$\begin{array}{l}\text { Parkinson's } \\
\text { Disease }\end{array}$} & Levodopa loaded SLN & $\begin{array}{l}\text { Physical stability and } \\
\text { entrapment efficiency } \\
\text { enhanced }\end{array}$ & In vitro & [199] \\
\hline & Bromocriptine loaded SLN & $\begin{array}{l}\text { To stabilize plasma levels } \\
\text { and increase CNS drug } \\
\text { concentration and half-life }\end{array}$ & In vivo & [200] \\
\hline & $\begin{array}{l}\text { Rotigotine loaded SLN } \\
\text { aerosol }\end{array}$ & $\begin{array}{l}\text { Oral inhalation } \\
\text { improvement }\end{array}$ & In vitro & [200] \\
\hline & Apomorphine loaded SLN & $\begin{array}{l}\text { Oral administration to } \\
\text { increase bioavailability }\end{array}$ & In vitro & {$[201]$} \\
\hline & Ropinirole loaded SLN & $\begin{array}{l}\text { Intranasal formulations for } \\
\text { alternative administration } \\
\text { route }\end{array}$ & In vitro and ex vivo & [202] \\
\hline \multirow[t]{2}{*}{$\begin{array}{l}\text { Huntington's } \\
\text { Disease }\end{array}$} & Curcumin loaded SLN & $\begin{array}{l}\text { Ameliorating } \\
\text { mitochondrial } \\
\text { dysfunctions }\end{array}$ & In vivo & [203] \\
\hline & $\begin{array}{l}\text { Rosmarinic acid loaded } \\
\text { SLN }\end{array}$ & $\begin{array}{l}\text { To enhance brain-targeting } \\
\text { efficiency through } \\
\text { intranasal administration } \\
\text { and ameliorate behavioral } \\
\text { dysfunctions associated } \\
\text { with HD }\end{array}$ & In vivo & [204] \\
\hline Multiple Sclerosis & Riluzole loaded SLN & $\begin{array}{l}\text { A higher capability to carry } \\
\text { the drug into the brain and } \\
\text { a lower indiscriminate } \\
\text { biodistribution }\end{array}$ & In vivo & [80] \\
\hline \multirow[t]{4}{*}{ Tumor/Cancer } & SLNs of etoposide & $\begin{array}{l}\text { Enhanced inhibitory effect } \\
\text { on proliferation of glioma } \\
\text { cell lines }\end{array}$ & In vitro & {$[205]$} \\
\hline & SLNs of paclitaxel & $\begin{array}{l}\text { Enhanced bioavailability } \\
\text { with tumor targeting }\end{array}$ & In vitro & {$[206]$} \\
\hline & $\begin{array}{l}\text { SLN loaded with } \\
\text { camptothecin }\end{array}$ & $\begin{array}{l}\text { Improve the circulation } \\
\text { time and brain } \\
\text { accumulation }\end{array}$ & In vivo & {$[207]$} \\
\hline & $\begin{array}{l}\text { SLN loaded with } \\
\text { doxorubicin }\end{array}$ & & In vivo & {$[208]$} \\
\hline
\end{tabular}


Table 4. Cont.

\begin{tabular}{|c|c|c|c|c|}
\hline CNS Disorder & SLNs & Function & $\begin{array}{c}\text { Study } \\
\text { Performed }\end{array}$ & Reference \\
\hline \multirow[t]{4}{*}{ Epilepsy } & $\begin{array}{l}\text { SLN loaded with } \\
\text { carbamazepine }\end{array}$ & Anticonvulsant effect & In vitro & [209] \\
\hline & SLN loaded with diazepam & $\begin{array}{l}\text { Significant and prolonged } \\
\text { release observed and good } \\
\text { encapsulation efficiency }\end{array}$ & In vitro & [210] \\
\hline & $\begin{array}{l}\text { SLN loaded with } \\
\text { clonazepam }\end{array}$ & $\begin{array}{l}\text { Enhanced blood-brain } \\
\text { barrier permeability }\end{array}$ & In vitro and In vivo & [211] \\
\hline & SLN loaded with raloxifene & $\begin{array}{l}\text { Increase in oral } \\
\text { bioavailability and } \\
\text { lymphatic absorption } \\
\text { and good physical stability }\end{array}$ & In vivo & [212] \\
\hline \multirow[t]{3}{*}{ Stroke } & SLN of curcumin & $\begin{array}{l}\text { Alleviated behavioral, } \\
\text { oxidative, and nitrosative } \\
\text { stress; acetylcholinesterase; } \\
\text { and mitochondrial enzyme } \\
\text { complex, and physiological } \\
\text { parameters }\end{array}$ & In vitro & [213] \\
\hline & Daidzein SLN & $\begin{array}{l}\text { Protective effect suffering } \\
\text { from ischemia-reperfusion } \\
\text { by increased cerebral blood } \\
\text { flow, reduced } \\
\text { cerebrovascular resistance } \\
\text { and brain targeting }\end{array}$ & In vitro & [214] \\
\hline & Vinpocetine SLN & $\begin{array}{l}\text { Target chronic cerebral } \\
\text { vascular ischemia or stroke } \\
\text { by brain targeting and } \\
\text { sustained release }\end{array}$ & In vitro & [215] \\
\hline \multirow[t]{3}{*}{ Neurodegeneration } & $\begin{array}{l}\text { SLN encapsulating } \\
\text { curcuminoids }\end{array}$ & Therapeutically effective & $\begin{array}{c}\text { In vivo and pre-clinical } \\
\text { Studies }\end{array}$ & [216] \\
\hline & Idebenone loaded SLN & $\begin{array}{l}\text { Improving brain delivery } \\
\text { and reducing cytotoxicity } \\
\text { and oxidative stress in } \\
\text { astrocytes from rat cerebral } \\
\text { cortex }\end{array}$ & In vitro & [152] \\
\hline & Luteolin SLN & $\begin{array}{l}\text { Improve the bioavailability } \\
\text { and pharmacokinetics of } \\
\text { compound }\end{array}$ & In vitro and in vivo & [217] \\
\hline
\end{tabular}

\subsection{Drug Loaded SLNs for Alzheimer's Disease}

$\mathrm{AD}$ is a progressively degenerative neuro disorder mainly affecting the aged society. It is characterized by frequent cognitive function loss such as loss of memory and frequent behavioral change, leading to death [218]. Its therapeutics are based on targeting cholinergic dysfunction in developing cholinesterase inhibitors [219]. Donepezil, galantamine, and rivastigmine are the FDA-approved drugs use as acetylcholinesterase inhibitors to treat various grades of AD [220]. However, the required drug concentration cannot be reached at the site of the brain, which is one of the major limitations of these drugs. The main cause of this is the inability of the drugs to cross the BBB, minimizing the pharmacological effect. Higher drug concentrations need to be reached to provide better neuroprotection. SLNs, as an advanced drug delivery approach, have been used to load the existing drugs, further improving bioavailability and therapeutic efficacy in treating AD [221,222]. Donepezil (an anti-Alzheimer's drug), when tailored to ApoE-targeted and SLN-based formulations, the 
in vitro study findings showed that it has enhanced drug delivery with a favorable release profile in CMEC/D3 brain endothelial cells and human SH-SY5Y neuronal cells [223]. SLNs loaded with galantamine hydrobromide is one of the most potent anti-AD drugs [192]. This drug composite has been synthesized by the solvent emulsification-diffusion technique, using Tween 80 as a surfactant. The resulting SLN has a particle size $(772 \pm 20 \mathrm{~nm})$, polydispersity index (PDI; 0.432), and Z-potential (14.8 $\pm 3 \mathrm{mV})$. Piperine loaded in SLN is another anti-AD drug studied in vivo by Yusuf et al. [194]. This SLN is synthesized by the solvent emulsification-diffusion technique using glycerol monostearate as a common solid lipid and Polysorbate-80 coating for specific brain targeting. Kakkar, et al. studied the curcumin loaded in SLN, synthesized by Compritol888, Polysorbate-80, and soy lecithin. This was employed in the microemulsification technique for the treatment of [198] aluminum-induced AD. The specialized SLN can overcome the poor absorption, instability at physiological $\mathrm{pH}$, rapid metabolism, and systemic elimination of drugs [216,224-226], improving the AD treatment strategy. The functionality of this, and related studies on SLNs loaded with nicotinamide, sesamol, galantamine, quercetin, piperine, ferulic acid, epigallocatechin3-gallate and curcumin, is briefly illustrated in Table 4.

\subsection{Drug Loaded SLNs for Parkinson's Disease}

Parkinson's disease (PD) is the second most common neurodegenerative disorder, after AD. It involves symptoms of psychological disorders, depression, tremor, and bradykinesia [227] with advancing age [228]. The pathological mechanism includes the progressive loss of the dopaminergic neuron as a result of mitochondrial dysfunction, oxidative stress, and protein misfolding. Levodopa is the best drug of choice for PD to date [229-231], targeting the dopaminergic receptor. Levodopa is able to cross the BBB. However, the required drug bioavailability is unsatisfactory [232,233], with lower therapeutic efficacy. The recent SLN drug delivery approach synthesized by the microemulsion technique was introduced to encapsulate the levodopa to overcome the limitations [199]. Bromocriptine loaded in SLNs synthesized by ultrasonication and homogenization (with a mean diameter of $197.5 \mathrm{~nm}$, PDI of 0.22 , and good stability for $>6$ months) is another drug of choice, with an increased CNS drug concentration and half-life when studied by Esposito et al. for the treatment of PD [200]. Apomorphine and ropinirole are other dopaminergic agonists, given through oral and intranasal routes, respectively, which have shown encouraging results in vitro, ex vivo and in vivo PD rat models [202]. SLNs loaded with levodopa, bromocriptine, rotigotine, apomorphine, and ropinirole are briefly detailed, alongside their functionality, in Table 4.

\subsection{Drug Loaded SLNs for Huntington's Disease}

HD is an autosomal dominant disorder resulting from a mutation in the huntingtin (HTT) gene, with severe neurological disturbances and phenotypes such as dementia, depression, schizophrenia, abnormal body movements, chorea, athetosis, oculomotor apraxia, bipolar disorders, and sometimes suicidal tendencies [234]. There is no successful treatment for HD. Several drugs can reduce the symptoms of HD, such as: FDA-approved tetrabenazine (Xenazine); deutetrabenazine (Austedo), haloperidol, risperidone (Risperdal), olanzapine (Zyprexa), quetiapine (Seroquel), amantadine (Gocovri ER, Osmolex ER), levetiracetam (Keppra, Elepsia XR, Spritam), and clonazepam (Klonopin) [235,236]. The treatment strategy for HD is still unsuccessful, due to the unusual behavior of the BBB as an obstacle for drug-crossing and targeting. Advanced SLN drug carriers can deliver the drug candidates targeting HD, as they are able to cross the BBB and reach the target site of CNS, resulting in better therapeutic activity. Curcumin-loaded SLNs are one such candidate; they were tested in vivo for the treatment of HD, reducing the severity [203]. This specialized SLN has been shown to recover the neuronal loss due to mitochondrial dysfunctions and oxidative stress in the HD brain. They can also be helpful in increasing the reduced glutathione (GSH) levels and superoxide dismutases (SOD) activity. Bhatt et al. studied a rosmarinic-acid-loaded SLN carrier's intranasal administration [204] for HD, 
looking at its neuroprotective qualities. The acted by reducing oxidative stress in HD in the in vivo animal models. In Table 4, the curcumin-loaded SLN and rosmarinic-acid-loaded SLN are presented, alongside their functionalities.

\subsection{Drug Loaded SLNs for Multiple Sclerosis}

Multiple sclerosis (MS) disables the CNS along with the brain and spinal cord, where the insulating covers of nerve cells in the brain and spinal cord are deactivated and damaged [237]. Therefore, the failure of signal transmission in the brain results in a range of devastating physical, mental, and psychiatric problems [238-240]. Certain FDAapproved drugs are available for clinical use such as: cladribine (Mavenclad), dimethyl fumarate (Tecfidera), diroximel fumarate (Vumerity), fingolimod (Gilenya), monomethyl fumarate (Bafiertam), ozanimod (Zeposia), siponimod (Mayzent), teriflunomide (Aubagio), interferon beta-1a (Avonex, Rebif), interferon beta-1b (Betaseron, Extavia), glatiramer acetate (Copaxone, Glatopa), peginterferon beta-1a (Plegridy), alemtuzumab (Lemtrada), mitoxantrone hydrochloride, natalizumab (Tysabri), and ocrelizumab (Ocrevus) to manage the severity of the MS symptoms and conditions. The bioavailability and plasma drug concentration are unsatisfactory, which many drugs showing reduced pharmacological activity. The current SLN-based drug delivery strategy has been shown to improve the efficacy of some drugs in the treatment of MS. The in vivo study based on riluzole-loaded SLNs, synthesized by microemulsion (average diameter $88 \pm 4$; PDI $0.27 \pm 0.03 \mathrm{~nm}$ ), has shown better brain delivery of the drug through the BBB. In comparison to other organs of the body, the brain showed a higher accumulation of the drug enhancing its neuroprotective abilities during the progression of MS and ALS in a rat model [241]. The functionality of SLNs loaded with the peculiar drug riluzole-loaded SLN are briefly described (Table 4).

\subsection{Drug Loaded SLNs for Brain Tumor and Cancer}

There are various grades of brain tumor in both nonmalignant and malignant forms; among these, glioblastoma is most prevalent, with a high risk of recurrence without successful treatment modality. The main obstacle to this is the difficulty in the effective transport of anti-cancer drugs across the BBB, resulting in lower therapeutic efficacy [242,243]. An advanced nano-drug carrier system is a novel approach to delivering a specific anticancer drug in a target-specific manner without affecting the normal, healthy cells [244]. A broad range of drugs and their modifications have been investigated for their ability to treat glioblastoma, such as the SLNs of etoposide [205] and paclitaxel [206]. In vitro studies demonstrated that these had an enhanced inhibitory effect on the proliferation of glioma cell lines, which was performed more efficiently than when using the free drug alone. Another study was based on anti-EGFR receptor functionalized cationic solid lipid nanoparticles (CASLNs) synthesized by the microemulsion method. The study demonstrated that the specialized SLN has anti-proliferative activity in targeting malignant glioblastoma cells [245]. The follow-up studies included in vitro studies of SLN composites of various drugs, including doxorubicin, and etoposide along with various targeting groups including aprotinin, anti-melanotransferrin, folic acid, p-aminophenyl- $\alpha$-D-manno-pyranoside, serotonergic 1B receptor subtype antagonist, 83-14 monoclonal antibody (8314Mab), anti-endothelial growth factor receptor, tamoxifen, and lactoferrin on HBMEC, human U87 malignant glioma, human astrocytes cell lines. The results showed SLNs to be nontoxic with antiproliferative effects. This could be attributed to the ability of these drug-loaded SLNs to infiltrate the BBB, suggesting their potential therapeutic use in future clinics for the treatment of multiple forms glioblastoma [245-249]. Other studies were conducted on SLNs loaded with the anticancer drug edelfosine synthesized by ultrasonication homogenization, when tested in vitro in a C6 glioma cell line and in vivo in a C6 glioma xenograft tumor. The results showed an anti-proliferative effect, with higher accumulation in the brain tissue, and a significant reduction in tumor growth [250]. Further research on SLNs of cetyl palmitate, stabilized with Tween ${ }^{\circledR} 60$ or Tween ${ }^{\circledR} 80$, carried out internalization studies in vitro and in vivo, and the results showed that the nanoparticles were internalized, leading to 
the increased therapeutic efficacy of the drug in crossing the BBB [251]. Another study aiming to enhance permeation through an in vitro BBB model, looked at the SLNs loaded with resveratrol functionalized with a targeting moiety, proving their inherent ability to passively target the brain [252]. SLNs loaded with paclitaxel and bevacizumab synthesized by the fatty acid coacervation technique, were found to penetrate the BBB (hCMEC/D3 cell monolayer in vitro BBB model) [253]. Anticancer drugs such as etoposide, paclitaxel, camptothecin, and doxorubicin loaded in SLNs are briefly presented, along with their functionalities, in Table 4.

\subsection{Drug Loaded SLNs for Epilepsy}

Overactivation of the electrical conductivity of the brain results in epilepsy, a CNS disorder resulting in partial or generalized seizures [254]. Here, the limitations of the therapeutics also include the inadequate concentration of drug delivery at the target site of the brain, due to the BBB serving as an obstacle. Among the conventional and recently developed drug delivery strategies, a nano-technological SLN based approach has shown possible advancements in overcoming the existing limitations in the treatment of epilepsy [255]. Recent research findings have shown promising results for SLNs loaded with carbamazepine with better anticonvulsant effect than nanoemulged-loaded carbamazepine [209]. Similarly, muscimol SLNs [256] and amiloride loaded SLNs [257] were evidenced to have anticonvulsant effects, suppressing focal seizures in in vivo rat models with a better and more sustained release in comparison to the administration of free drugs only. Details of SLNs loaded with carbamazepine, diazepam, clonazepam, and raloxifene are briefly explained in Table 4 .

\subsection{Drug Loaded SLNs in Ischemic Stroke}

Ischemic stroke is the abrupt loss of the neurological function of the brain, leading to permanent disability caused by the sudden loss of blood and oxygen supply [258]. There are several types of ischemic strokes, such as lacunar, cardioembolic, and cryptogenic strokes, and hemorrhagic strokes [259]. Although this deformity of the brain results in a maximum rate of morbidity and mortality in the worldwide population, there is no effective therapeutic solution to date. Furthermore, during an ischemic stroke the brain tissue damage is a progressive process. Ischemic stroke starts with hypoxia following a secondary consequence such as severe inflammation in the brain tissue and reactive oxygen species (ROS) production, and glutamate excitotoxicity. Gradually, brain edema, BBB damage, and nerve tissue damage result in associated disorders including neuronal cell death [260-262]. The major treatment approach should be based on how to reduce proinflammatory consequences and providing neuroprotection [263]. The current treatment strategies are futile, due to the restricted bioavailability of the drugs across the BBB. An advanced nanodrug delivery approach may contribute a novel treatment strategy to overcome the major hurdles during drug targeting for stroke management [264]. SLN carrier-based drug delivery is one of the current nanotechnological approaches looking at potential drug formulations for ischemic stroke therapeutics. Some primary study findings revealed that SLNs loaded with vincristine and temozolomide, synthesized by the highshear homogenization technique, have a profound, sustained release, suggesting future clinical use as a controlled delivery system [265]. The SLNs loaded with curcumin (as an antioxidant) have also gained particular interest in terms of their use in stroke treatment [266]. This study reports that SLN-encapsulated curcumin has a better therapeutic effect compared to free curcumin in inhibiting acetylcholinesterase levels and enhancing glutathione (GSH), superoxide dismutase (SOD), and catalase level. Another study focused on SLNs containing baicalin, and their actions against ischemic stroke, revealing the neuroprotective properties of encapsulated baicalin with improved bioavailability and stability [267]. Vinpocetine loaded in a specialized SLN formulation may overcome the short-comings, such as a lower bioavailability and short half-life associated with free vinpocetine in the treatment of chronic cerebral vascular ischemia [215]. Another study 
developed a surface modified (with apolipoprotein E: ApoE) resveratrol-loaded SLN on its surface, which can be identified by low-density lipoprotein (LDL) receptors in the BBB. Hence, this functionalized SLN drug carrier showed better BBB permeability in in vitro cell model [268]. In ischemic rat models, neurobehavioral deficits were improved significantly by ferulic acid (FA) loaded NLC, with improved bioavailability and reduced oxidative stress and neurotoxicity [269]. In Table 4, SLNs of curcumin, daidzein, and vinpocetine are presented, along with their functionalities.

\subsection{Drug Loaded SLN for Other Neurodegenerative Diseases}

Oxidative stress is a general hallmark of major neurodegenerative disorders, leading to neuronal cell dysfunction and progressive death [270]. Glutathione (GSH), lipoic acid (LA), carnosine, and caffeic acid provide potent antioxidant assistance in counteracting the free radicals produced by the ROS [222,271]. One study revealed that SLNs encapsulating LA can be used for the topical delivery of LA as an antiaging agent [272], with enhanced stability and hydrophilicity [273]. Another study found that lipoyl-memantine (LA-MEM codrug)-loaded SLNs are an innovative approach, which are stable in simulated gastric and intestinal fluids, improving stability, solubility and absorption through the gastrointestinal tract. This suggests that they can cross the BBB at maximum concentrations. Furthermore, LA and MEM were released as the end product of hydrolysis, exhibiting therapeutic efficacy in a safe and nontoxic manner [273]. Idebenone is another antioxidant drug of choice, loaded into SLN as a potent drug delivery system to the brain [152,228]. The in vitro study on the primary cultures of rat cerebral cortex astrocytes showed that idebenone-loaded SLNs were able to inhibit 2,2'-azobis-(2-amidinopropane) dihydrochloride (APPH)-induced lactic dehydrogenase (LDH) release, and ROS production. This idebenone-loaded SLN could be an interesting carrier system to pass the BBB, enhancing drug bioavailability in the brain. Luteolin (LU, 5,7,30,40-tetrahydroxyflavone) -loaded SLNs, synthesized by hot-microemulsion [217], have been shown to reduce oxidative stress in vivo in the management of neurodegenerative disorders. Interestingly, in vitro studies showed that $\mathrm{AD}$ and $\mathrm{PD}$ associated with severe neurodegeneration could be treated by resveratrol (a natural polyphenolic flavonoid) and grape-extract-loaded solid lipid nanoparticles, which enhance the regeneration of damaged neurons through crossing the BBB [274,275]. SLNs encapsulating curcuminoids, idebenone, and luteolin SLN are briefly summarized in Table 4.

This review paper emphasized a large number of drugs loaded SLNs and their therapeutic evaluation having potential for the treatment of various neurological disorders in future clinics. Even more interestingly, the SLNs formulations have exhibited the potency of crossing the BBB in the in vitro and in vivo models. Nonetheless, few of them have been approved in clinical context only in the treatment of cardiac diseases and some cancers, and not for neurological disorders in crossing the BBB [276,277]. There is no relevant clinical study for SLN containing drug for neurological disorders. However, the clinical study showed that [278], in comparison to only melatonin, administration of SLN loaded with melatonin was adequate to obtain better pharmacological levels even in the early phase of critical illness, with a favorable pharmacokinetic profile. This could be useful to achieve a sleep-inducing effect. Encapsulation into lipid nano vectors might offer some advantages from a pharmacokinetics point of view. Transdermal administration may represent an effective alternative to mimic the endogenous pattern of melatonin blood levels, possibly helping in restoring the circadian cycle in critically ill patients. More substantially, the major unsatisfactory consequences discovered during preclinical study are an inconsistent result of the SLN loaded drug, showing variable pharmacokinetic profiles in different animal models during crossing the BBB. This deviation in results of drug efficacy may be due to diverse brain microenvironments in the animal models. In this scenario further critical research is prerequisite to evaluate the bioavailability of the SLNs in predicting their pharmacological action and drug uptake in animal models, whose neurophysiology closely resembles that of humans. Hence, there is a better possibility of 
clinical approval of the SLNs in treatment of neurological disorders in targeting the BBB and their further commercialization.

\section{Conclusions}

To date, the treatment of CNS disorders is an onerous task in the field of medicine. The rate of mortality and morbidity is still an unresolved issue associated with complex neuropathologies, as well as the mechanisms behind the disorders, and BBB serves as a barrier for most of the therapeutic drugs. Recent biomedical research has made considerable progress in understanding the BBB as a potential target for brain drug delivery. In this context, much attention should be paid to the BBB not only as physical barrier, but also as a novel therapeutic target for a specific kind of drug delivery to CNS for the treatment of brain disorders. Among the lipid-based advanced nano-drug-delivery carrier systems, SLNs and their modification as a new therapeutics method, aimed to overcome the hindrances caused by the BBB. They have shown improved pharmacological applications. Furthermore, due to their unique physicochemical nature they can deliver the active drug contents in a targetspecific and controlled manner, with fewer possible toxicity issues. Moreover, SLNs offer clinical advantages for effective brain drug delivery, with reduced side effects, an increased drug half-life, and the possibility of enhancing drugs' ability to cross the BBB. Despite this, SLN has certain limitations, such as a lower drug payload, the complex physical state of the lipid content, and stability problems during storage and administration (gelation, increase in particle size, drug expulsion). Based on the current drawbacks associated with SLNs, futuristic development is needed to make them an ideal CNS drug delivery approach for treating the maximum number of neurological disorders. Finally, although current SLN strategies could not successfully cure neurological disorders, technological advancements and better understanding of the BBB transport mechanism can provide new hope in the development of this novel therapeutic strategy. Besides this, the standardization of the modified synthetic strategies, optimization of the sterilization process, scaling up of the manufacturing processes, and current stability issues are some of the challenges that need to be overcome before SLNs are approved for clinical use.

Author Contributions: M.K.S. and C.-H.Y. conceived the concept of the review paper. T.-L.Y., J.-S.J. and R.-D.T. drew the images and tables. M.K.S., J.-Y.W., R.T. and C.-H.Y. wrote the manuscript. All the authors discussed, edited, and approved the final version of the manuscript. All authors have read and agreed to the published version of the manuscript.

Funding: This work was supported by grants from the Ministry of Science and Technology of Taiwan (MOST-106-2320-B-038-049-MY3 and MOST-108-2314-B-038-022).

Conflicts of Interest: The authors declare no conflict of interest.

\section{References}

1. Choonara, Y.E.; Pillay, V.; Du Toit, L.C.; Modi, G.; Naidoo, D.; Ndesendo, V.M.; Sibambo, S.R. Trends in the molecular pathogenesis and clinical therapeutics of common neurodegenerative disorders. Int. J. Mol. Sci. 2009, 10, 2510-2557. [CrossRef] [PubMed]

2. Lauretani, F.; Maggio, M.; Silvestrini, C.; Nardelli, A.; Saccavini, M.; Ceda, G.P. Parkinson's disease (PD) in the elderly: An example of geriatric syndrome (GS)? Arch. Gerontol. Geriatr. 2012, 54, 242-246. [CrossRef]

3. Glorioso, C.; Oh, S.; Douillard, G.G.; Sibille, E. Brain molecular aging, promotion of neurological disease and modulation by Sirtuin5 longevity gene polymorphism. Neurobiol. Dis. 2011, 41, 279-290. [CrossRef]

4. Glorioso, C.; Sibille, E. Between destiny and disease: Genetics and molecular pathways of human central nervous system aging. Prog. Neurobiol. 2011, 93, 165-181. [CrossRef] [PubMed]

5. Patel, M.; Souto, E.B.; Singh, K.K. Advances in brain drug targeting and delivery: Limitations and challenges of solid lipid nanoparticles. Expert Opin. Drug Deliv. 2013, 10, 889-905. [CrossRef]

6. Barchet, T.M.; Amiji, M.M. Challenges and opportunities in CNS delivery of therapeutics for neurodegenerative diseases. Expert Opin. Drug Deliv. 2009, 6, 211-225. [CrossRef] [PubMed]

7. Scheffel, U.; Rhodes, B.A.; Natarajan, T.; Wagner, H.N. Albumin microspheres for study of the reticuloendothelial system. J. Nucl. Med. 1972, 13, 498-503.

8. Sawant, K.K.; Dodiya, S.S. Recent advances and patents on solid lipid nanoparticles. Recent Pat. Drug Deliv. Formul. 2008, 2, 120-135. [CrossRef] [PubMed] 
9. Begley, D.J. Delivery of therapeutic agents to the central nervous system: The problems and the possibilities. Pharmacol. Ther. 2004, 104, 29-45. [CrossRef] [PubMed]

10. Cecchelli, R.; Berezowski, V.; Lundquist, S.; Culot, M.; Renftel, M.; Dehouck, M.-P.; Fenart, L. Modelling of the blood-brain barrier in drug discovery and development. Nat. Rev. Drug Discov. 2007, 6, 650-661. [CrossRef] [PubMed]

11. Zhou, J.; Atsina, K.-B.; Himes, B.T.; Strohbehn, G.W.; Saltzman, W.M. Novel delivery strategies for glioblastoma. Cancer J. 2012, 18, 89-99. [CrossRef] [PubMed]

12. Newton, H.B. Advances in strategies to improve drug delivery to brain tumors. Expert Rev. Neurother. 2006, 6, 1495-1509. [CrossRef] [PubMed]

13. Harris, J.J.; Jolivet, R.; Attwell, D. Synaptic energy use and supply. Neuron 2012, 75, 762-777. [CrossRef] [PubMed]

14. Iadecola, C.; Yaffe, K.; Biller, J.; Bratzke, L.C.; Faraci, F.M.; Gorelick, P.B.; Gulati, M.; Kamel, H.; Knopman, D.S.; Launer, L.J Impact of hypertension on cognitive function: A scientific statement from the American Heart Association. Hypertension 2016, 68, e67-e94. [CrossRef] [PubMed]

15. Zlokovic, B.V. The blood-brain barrier in health and chronic neurodegenerative disorders. Neuron 2008, 57, 178-201. [CrossRef] [PubMed]

16. Zlokovic, B.V. Neurovascular pathways to neurodegeneration in Alzheimer's disease and other disorders. Nat. Rev. Neurosci. 2011, 12, 723-738. [CrossRef]

17. Pardridge, W.M. Drug transport across the blood-brain barrier. J. Cereb. Blood Flow Metab. 2012, 32, 1959-1972. [CrossRef]

18. Abbott, N.J. Astrocyte-endothelial interactions and blood-brain barrier permeability. J. Anat. 2002, 200, 523-534. [CrossRef]

19. Pardridge, W.M. Molecular biology of the blood-brain barrier. Mol. Biotechnol. 2005, 30, 57-69. [CrossRef]

20. Levin, V.A. Relationship of octanol/water partition coefficient and molecular weight to rat brain capillary permeability. J. Med. Chem. 1980, 23, 682-684. [CrossRef]

21. Van De Waterbeemd, H.; Smith, D.A.; Beaumont, K.; Walker, D.K. Property-based design: Optimization of drug absorption and pharmacokinetics. J. Med. Chem. 2001, 44, 1313-1333. [CrossRef]

22. Patel, M.M.; Goyal, B.R.; Bhadada, S.V.; Bhatt, J.S.; Amin, A.F. Getting into the brain. CNS Drugs 2009, 23, 35-58. [CrossRef]

23. Chaichana, K.L.; Pinheiro, L.; Brem, H. Delivery of local therapeutics to the brain: Working toward advancing treatment for malignant gliomas. Ther. Deliv. 2015, 6, 353-369. [CrossRef]

24. Erdő, F.; Bors, L.A.; Farkas, D.; Bajza, Á.; Gizurarson, S. Evaluation of intranasal delivery route of drug administration for brain targeting. Brain Res. Bull. 2018, 143, 155-170. [CrossRef]

25. Agrawal, M.; Saraf, S.; Saraf, S.; Antimisiaris, S.G.; Chougule, M.B.; Shoyele, S.A.; Alexander, A. Nose-to-brain drug delivery: An update on clinical challenges and progress towards approval of anti-Alzheimer drugs. J. Control. Release 2018, 281, 139-177. [CrossRef]

26. Pires, P.C.; Santos, A.O. Nanosystems in nose-to-brain drug delivery: A review of non-clinical brain targeting studies. J. Control. Release 2018, 270, 89-100. [CrossRef]

27. Mistry, A.; Stolnik, S.; Illum, L. Nanoparticles for direct nose-to-brain delivery of drugs. Int. J. Pharm. 2009, 379, 146-157. [CrossRef]

28. Bourganis, V.; Kammona, O.; Alexopoulos, A.; Kiparissides, C. Recent advances in carrier mediated nose-to-brain delivery of pharmaceutics. Eur. J. Pharm. Biopharm. 2018, 128, 337-362. [CrossRef]

29. Gänger, S.; Schindowski, K. Tailoring formulations for intranasal nose-to-brain delivery: A review on architecture, physicochemical characteristics and mucociliary clearance of the nasal olfactory mucosa. Pharmaceutics 2018, 10, 116. [CrossRef]

30. Lochhead, J.J.; Thorne, R.G. Intranasal delivery of biologics to the central nervous system. Adv. Drug Deliv. Rev. 2012, 64, 614-628. [CrossRef]

31. Posadas, I.; Monteagudo, S.; Ceña, V. Nanoparticles for brain-specific drug and genetic material delivery, imaging and diagnosis. Nanomedicine 2016, 11, 833-849. [CrossRef]

32. Blanchette, M.; Fortin, D. Blood-brain barrier disruption in the treatment of brain tumors. In The Blood-Brain and Other Neural Barriers; Springer: Berlin/Heidelberg, Germany, 2011; pp. 447-463.

33. Etame, A.B.; Diaz, R.J.; O’Reilly, M.A.; Smith, C.A.; Mainprize, T.G.; Hynynen, K.; Rutka, J.T. Enhanced delivery of gold nanoparticles with therapeutic potential into the brain using MRI-guided focused ultrasound. Nanomed. Nanotechnol. Biol. Med. 2012, 8, 1133-1142. [CrossRef]

34. Bing, K.F.; Howles, G.P.; Qi, Y.; Palmeri, M.L.; Nightingale, K.R. Blood-brain barrier (BBB) disruption using a diagnostic ultrasound scanner and Definity®in mice. Ultrasound Med. Biol. 2009, 35, 1298-1308. [CrossRef] [PubMed]

35. Tapeinos, C.; Battaglini, M.; Ciofani, G. Advances in the design of solid lipid nanoparticles and nanostructured lipid carriers for targeting brain diseases. J. Control. Release 2017, 264, 306-332. [CrossRef]

36. Anthony, D.P.; Hegde, M.M.; Shetty, S.S.; Rafic, T.; Mutalik, S.; Rao, B.S. Targeting receptor-ligand chemistry for drug delivery across blood-brain barrier in brain diseases. Life Sci. 2021, 274, 119326. [CrossRef] [PubMed]

37. Alavijeh, M.S.; Chishty, M.; Qaiser, M.Z.; Palmer, A.M. Drug metabolism and pharmacokinetics, the blood-brain barrier, and central nervous system drug discovery. NeuroRx 2005, 2, 554-571. [CrossRef]

38. Rakotoarisoa, M.; Angelova, A. Amphiphilic nanocarrier systems for curcumin delivery in neurodegenerative disorders. Medicines 2018, 5, 126. [CrossRef] 
39. Jumaa, M.; Müller, B.W. Lipid emulsions as a novel system to reduce the hemolytic activity of lytic agents: Mechanism of the protective effect. Eur. J. Pharm. Sci. 2000, 9, 285-290. [CrossRef]

40. Kaur, I.P.; Bhandari, R.; Bhandari, S.; Kakkar, V. Potential of solid lipid nanoparticles in brain targeting. J. Control. Release 2008, 127, 97-109. [CrossRef]

41. Chen, D.-B.; Yang, T.-Z.; Lu, W.-L.; Zhang, Q. In vitro and in vivo study of two types of long-circulating solid lipid nanoparticles containing paclitaxel. Chem. Pharm. Bull. 2001, 49, 1444-1447. [CrossRef]

42. Pardeshi, C.; Rajput, P.; Belgamwar, V.; Tekade, A.; Patil, G.; Chaudhary, K.; Sonje, A. Solid lipid based nanocarriers: An overview. Acta Pharm. 2012, 62, 433-472. [CrossRef]

43. Müller, R.H.; Mäder, K.; Gohla, S. Solid lipid nanoparticles (SLN) for controlled drug delivery-A review of the state of the art. Eur. J. Pharm. Biopharm. 2000, 50, 161-177. [CrossRef]

44. Freitas, C.; Müller, R.H. Effect of light and temperature on zeta potential and physical stability in solid lipid nanoparticle (SLN ${ }^{\mathrm{TM}}$ ) dispersions. Int. J. Pharm. 1998, 168, 221-229. [CrossRef]

45. Mukherjee, S.; Ray, S.; Thakur, R. Solid lipid nanoparticles: A modern formulation approach in drug delivery system. Indian J. Pharm. Sci. 2009, 71, 349. [CrossRef] [PubMed]

46. Tabatt, K.; Kneuer, C.; Sameti, M.; Olbrich, C.; Müller, R.H.; Lehr, C.-M.; Bakowsky, U. Transfection with different colloidal systems: Comparison of solid lipid nanoparticles and liposomes. J. Control. Release 2004, 97, 321-332. [CrossRef] [PubMed]

47. Hamdani, J.; Moës, A.J.; Amighi, K. Physical and thermal characterisation of Precirol@and Compritol@as lipophilic glycerides used for the preparation of controlled-release matrix pellets. Int. J. Pharm. 2003, 260, 47-57. [CrossRef]

48. Mosallaei, N.; Jaafari, M.R.; Hanafi-Bojd, M.Y.; Golmohammadzadeh, S.; Malaekeh-Nikouei, B. Docetaxel-loaded solid lipid nanoparticles: Preparation, characterization, in vitro, and in vivo evaluations. J. Pharm. Sci. 2013, 102, 1994-2004. [CrossRef]

49. Yang, S.C.; Lu, L.F.; Cai, Y.; Zhu, J.B.; Liang, B.W.; Yang, C.Z. Body distribution in mice of intravenously injected camptothecin solid lipid nanoparticles and targeting effect on brain. J. Control. Release 1999, 59, 299-307. [CrossRef]

50. Manjunath, K.; Venkateswarlu, V. Pharmacokinetics, tissue distribution and bioavailability of clozapine solid lipid nanoparticles after intravenous and intraduodenal administration. J. Control. Release 2005, 107, 215-228. [CrossRef]

51. Gohla, S.; Dingler, A. Scaling up feasibility of the production of solid lipid nanoparticles (SLN). Die Pharm. 2001, 56, 61-63.

52. Sathali, A.H.; Ekambaram, P.; Priyanka, K. Solid lipid nanoparticles: A review. Sci. Revs. Chem. Commun 2012, 2, 80-102.

53. Reddy, A.; Parthiban, S.; Vikneswari, A.; Senthilkumar, G. A modern review on solid lipid nanoparticles as novel controlled drug delivery system. Int. J. Res. Pharm. Nano Sci. 2014, 3, 313-325.

54. Garud, A.; Singh, D.; Garud, N. Solid lipid nanoparticles (SLN): Method, characterization and applications. Int. Curr. Pharm. J. 2012, 1, 384-393. [CrossRef]

55. Schwarz, C. Solid lipid nanoparticles (SLN) for controlled drug delivery II. Drug incorporation and physicochemical characterization. J. Microencapsul. 1999, 16, 205-213. [CrossRef]

56. Freitas, C.; Müller, R. Correlation between long-term stability of solid lipid nanoparticles (SLN ${ }^{\mathrm{TM}}$ ) and crystallinity of the lipid phase. Eur. J. Pharm. Biopharm. 1999, 47, 125-132. [CrossRef]

57. Fundarò, A.; Cavalli, R.; Bargoni, A.; Vighetto, D.; Zara, G.P.; Gasco, M.R. Non-stealth and stealth solid lipid nanoparticles (SLN) carrying doxorubicin: Pharmacokinetics and tissue distribution after iv administration to rats. Pharmacol. Res. 2000, 42, 337-343. [CrossRef] [PubMed]

58. Reddy, J.S.; Venkateswarlu, V. Novel delivery systems for drug targeting to the brain. Drugs Future 2004, 29, 63-83. [CrossRef]

59. Baek, J.-S.; Cho, C.-W. Surface modification of solid lipid nanoparticles for oral delivery of curcumin: Improvement of bioavailability through enhanced cellular uptake, and lymphatic uptake. Eur. J. Pharm. Biopharm. 2017, 117, 132-140. [CrossRef] [PubMed]

60. Lockman, P.R.; Oyewumi, M.O.; Koziara, J.M.; Roder, K.E.; Mumper, R.J.; Allen, D.D. Brain uptake of thiamine-coated nanoparticles. J. Control. Release 2003, 93, 271-282. [CrossRef]

61. Dingler, A. Feste Lipid-Nanopartikel als Kolloidale Wirkstoffträgersysteme zur Dermalen Applikation. Ph.D. Thesis, Freie Universität Berlin, Berlin, Germany, 1998.

62. Müller, R.; Mehnert, W.; Lucks, J.-S.; Schwarz, C.; Zur Mühlen, A. Solid lipid nanoparticles (SLN): An alternative colloidal carrier system for controlled drug delivery. Eur. J. Pharm. Biopharm. 1995, 41, 62-69.

63. zur Mühlen, A.; Schwarz, C.; Mehnert, W. Solid lipid nanoparticles (SLN) for controlled drug delivery-drug release and release mechanism. Eur. J. Pharm. Biopharm. 1998, 45, 149-155. [CrossRef]

64. Sun, J.; Bi, C.; Chan, H.M.; Sun, S.; Zhang, Q.; Zheng, Y. Curcumin-loaded solid lipid nanoparticles have prolonged in vitro antitumour activity, cellular uptake and improved in vivo bioavailability. Colloids Surf. B Biointerfaces 2013, 111, 367-375. [CrossRef] [PubMed]

65. Huang, X.; Chen, Y.-J.; Peng, D.-Y.; Li, Q.-L.; Wang, X.-S.; Wang, D.-L.; Chen, W.-D. Solid lipid nanoparticles as delivery systems for Gambogenic acid. Colloids Surf. B Biointerfaces 2013, 102, 391-397. [CrossRef] [PubMed]

66. Jain, V.; Gupta, A.; Pawar, V.K.; Asthana, S.; Jaiswal, A.K.; Dube, A.; Chourasia, M.K. Chitosan-assisted immunotherapy for intervention of experimental leishmaniasis via amphotericin B-loaded solid lipid nanoparticles. Appl. Biochem. Biotechnol. 2014, 174, 1309-1330. [CrossRef] [PubMed]

67. Rawat, M.K.; Jain, A.; Singh, S. Studies on binary lipid matrix based solid lipid nanoparticles of repaglinide: In vitro and in vivo evaluation. J. Pharm. Sci. 2011, 100, 2366-2378. [CrossRef] [PubMed] 
68. Westesen, K.; Bunjes, H.; Koch, M. Physicochemical characterization of lipid nanoparticles and evaluation of their drug loading capacity and sustained release potential. J. Control. Release 1997, 48, 223-236. [CrossRef]

69. Westesen, K.; Siekmann, B.; Koch, M.H. Investigations on the physical state of lipid nanoparticles by synchrotron radiation X-ray diffraction. Int. J. Pharm. 1993, 93, 189-199. [CrossRef]

70. Di, L.; Kerns, E.H.; Hong, Y.; Chen, H. Development and application of high throughput plasma stability assay for drug discovery. Int. J. Pharm. 2005, 297, 110-119. [CrossRef]

71. Djuzenova, C.S.; Güttler, T.; Berger, S.; Katzer, A.; Flentje, M. Differential response of human glioblastoma cell lines to combined camptothecin and ionizing radiation treatment. Cancer Biol. Ther. 2008, 7, 364-373. [CrossRef]

72. Tsai, T.; Lee, C.; Yeh, P. Effect of P-glycoprotein modulators on the pharmacokinetics of camptothecin using microdialysis. Br. J. Pharmacol. 2001, 134, 1245-1252. [CrossRef]

73. Yang, S.; Zhu, J.; Lu, Y.; Liang, B.; Yang, C. Body distribution of camptothecin solid lipid nanoparticles after oral administration. Pharm. Res. 1999, 16, 751-757. [CrossRef] [PubMed]

74. Martins, S.M.; Sarmento, B.; Nunes, C.; Lúcio, M.; Reis, S.; Ferreira, D.C. Brain targeting effect of camptothecin-loaded solid lipid nanoparticles in rat after intravenous administration. Eur. J. Pharm. Biopharm. 2013, 85, 488-502. [CrossRef]

75. Martins, S.; Tho, I.; Reimold, I.; Fricker, G.; Souto, E.; Ferreira, D.; Brandl, M. Brain delivery of camptothecin by means of solid lipid nanoparticles: Formulation design, in vitro and in vivo studies. Int. J. Pharm. 2012, 439, 49-62. [CrossRef]

76. Manjunath, K.; Venkateswarlu, V. Pharmacokinetics, tissue distribution and bioavailability of nitrendipine solid lipid nanoparticles after intravenous and intraduodenal administration. J. Drug Target. 2006, 14, 632-645. [CrossRef]

77. Wang, J.-X.; Sun, X.; Zhang, Z.-R. Enhanced brain targeting by synthesis of $3^{\prime}, 5^{\prime}$-dioctanoyl-5-fluoro-2' -deoxyuridine and incorporation into solid lipid nanoparticles. Eur. J. Pharm. Biopharm. 2002, 54, 285-290. [CrossRef]

78. Madan, J.; Pandey, R.S.; Jain, V.; Katare, O.P.; Chandra, R.; Katyal, A. Poly (ethylene)-glycol conjugated solid lipid nanoparticles of noscapine improve biological half-life, brain delivery and efficacy in glioblastoma cells. Nanomed. Nanotechnol. Biol. Med. 2013, 9, 492-503. [CrossRef]

79. Zara, G.P.; Cavalli, R.; Fundarò, A.; Bargoni, A.; Caputo, O.; Gasco, M.R. Pharmacokinetics of doxorubicin incorporated in solid lipid nanospheres (SLN). Pharmacol. Res. 1999, 40, 281-286. [CrossRef] [PubMed]

80. Bondì, M.L.; Craparo, E.F.; Giammona, G.; Drago, F. Brain-targeted solid lipid nanoparticles containing riluzole: Preparation, characterization and biodistribution. Nanomedicine 2010, 5, 25-32. [CrossRef]

81. Koziara, J.M.; Lockman, P.R.; Allen, D.D.; Mumper, R.J. Paclitaxel nanoparticles for the potential treatment of brain tumors. J. Control. Release 2004, 99, 259-269. [CrossRef] [PubMed]

82. Sweeney, M.D.; Sagare, A.P.; Zlokovic, B.V. Blood-brain barrier breakdown in Alzheimer disease and other neurodegenerative disorders. Nat. Rev. Neurol. 2018, 14, 133-150. [CrossRef] [PubMed]

83. Abbott, N.J.; Rönnbäck, L.; Hansson, E. Astrocyte-endothelial interactions at the blood-brain barrier. Nat. Rev. Neurosci. 2006, 7, 41-53. [CrossRef]

84. Sanchez-Covarrubias, L.; Slosky, L.M.; Thompson, B.J.; Davis, T.P.; Ronaldson, P.T. Transporters at CNS barrier sites: Obstacles or opportunities for drug delivery? Curr. Pharm. Des. 2014, 20, 1422-1449. [CrossRef]

85. Ballabh, P.; Braun, A.; Nedergaard, M. The blood-brain barrier: An overview: Structure, regulation, and clinical implications. Neurobiol. Dis. 2004, 16, 1-13. [CrossRef]

86. Banks, W.A.; Owen, J.B.; Erickson, M.A. Insulin in the brain: There and back again. Pharmacol. Ther. 2012, 136, 82-93. [CrossRef]

87. Boado, R.J.; Li, J.Y.; Nagaya, M.; Zhang, C.; Pardridge, W.M. Selective expression of the large neutral amino acid transporter at the blood-brain barrier. Proc. Natl. Acad. Sci. USA 1999, 96, 12079-12084. [CrossRef]

88. Zhang, Z.; Zhan, C. Receptor-mediated transportation through BBB. In Brain Targeted Drug Delivery System; Elsevier: Amsterdam, The Netherlands, 2019; pp. 105-128.

89. Villaseñor, R.; Lampe, J.; Schwaninger, M.; Collin, L. Intracellular transport and regulation of transcytosis across the blood-brain barrier. Cell. Mol. Life Sci. 2019, 76, 1081-1092. [CrossRef]

90. Pulgar, V.M. Transcytosis to cross the blood brain barrier, new advancements and challenges. Front. Neurosci. 2019, 12, 1019. [CrossRef]

91. Jones, A.R.; Shusta, E.V. Blood-brain barrier transport of therapeutics via receptor-mediation. Pharm. Res. 2007, 24, 1759-1771. [CrossRef]

92. Preston, J.E.; Abbott, N.J.; Begley, D.J. Transcytosis of macromolecules at the blood-brain barrier. Adv. Pharmacol. 1995, 71, 147-163.

93. Hervé, F.; Ghinea, N.; Scherrmann, J.-M. CNS delivery via adsorptive transcytosis. AAPS J. 2008, 10, 455-472. [CrossRef]

94. Lu, W. Adsorptive-mediated brain delivery systems. Curr. Pharm. Biotechnol. 2012, 13, 2340-2348. [CrossRef]

95. Zhu, X.; Jin, K.; Huang, Y.; Pang, Z. Brain drug delivery by adsorption-mediated transcytosis. In Brain Targeted Drug Delivery System; Elsevier: Amsterdam, The Netherlands, 2019; pp. 159-183.

96. Bickel, U.; Yoshikawa, T.; Pardridge, W.M. Pardridge, Delivery of peptides and proteins through the blood-brain barrier. Adv. Drug Deliv. Rev. 1993, 10, 205-245. [CrossRef]

97. Cavalli, R.; Caputo, O.; Gasco, M.R. Preparation and characterization of solid lipid nanospheres containing paclitaxel. Eur. J. Pharm. Sci. 2000, 10, 305-309. [CrossRef] 
98. Chen, L.-T.; Weiss, L. The role of the sinus wall in the passage of erythrocytes through the spleen. Blood 1973, 41, 529-537. [CrossRef]

99. Moghimi, S.M.; Porter, C.; Muir, I.; Illum, L.; Davis, S. Non-phagocytic uptake of intravenously injected microspheres in rat spleen: Influence of particle size and hydrophilic coating. Biochem. Biophys. Res. Commun. 1991, 177, 861-866. [CrossRef]

100. Jain, N. Advances in Controlled and Novel Drug Delivery; CBS Publishers \& Distributors: New Delhi, India, 2008.

101. Olivier, J.-C. Drug transport to brain with targeted nanoparticles. NeuroRx 2005, 2, 108-119. [CrossRef]

102. Oyewumi, M.O.; Yokel, R.A.; Jay, M.; Coakley, T.; Mumper, R.J. Comparison of cell uptake, biodistribution and tumor retention of folate-coated and PEG-coated gadolinium nanoparticles in tumor-bearing mice. J. Control. Release 2004, 95, 613-626. [CrossRef]

103. Kreuter, J. Nanoparticulate systems for brain delivery of drugs. Adv. Drug Deliv. Rev. 2001, 47, 65-81. [CrossRef]

104. Alyautdin, R.N.; Petrov, V.E.; Langer, K.; Berthold, A.; Kharkevich, D.A.; Kreuter, J. Delivery of loperamide across the blood-brain barrier with polysorbate 80-coated polybutylcyanoacrylate nanoparticles. Pharm. Res. 1997, 14, 325-328. [CrossRef]

105. Zara, G.P.; Cavalli, R.; Bargoni, A.; Fundarò, A.; Vighetto, D.; Gasco, M.R. Intravenous administration to rabbits of non-stealth and stealth doxorubicin-loaded solid lipid nanoparticles at increasing concentrations of stealth agent: Pharmacokinetics and distribution of doxorubicin in brain and other tissues. J. Drug Target. 2002, 10, 327-335. [CrossRef]

106. Carmona-Ribeiro, A.M.; Barbassa, L.; De Melo, L.D. Antimicrobial biomimetics. In Biomimetic Based Applications; IntechOpen: London, UK, 2011.

107. Bargoni, A.; Cavalli, R.; Zara, G.P.; Fundarò, A.; Caputo, O.; Gasco, M.R. Transmucosal transport of tobramycin incorporated in solid lipid nanoparticles (SLN) after duodenal administration to rats. Part II-Tissue distribution. Pharmacol. Res. 2001, 43, 497-502. [CrossRef]

108. Pardridge, W.M. Drug and gene targeting to the brain with molecular Trojan horses. Nat. Rev. Drug Discov. 2002, 1, 131-139. [CrossRef] [PubMed]

109. Tiwari, S.B.; Amiji, M.M. A review of nanocarrier-based CNS delivery systems. Curr. Drug Deliv. 2006, 3, 219-232. [CrossRef]

110. Thöle, M.; Nobmann, S.; Huwyler, J.; Bartmann, A.; Fricker, G. Uptake of cationized albumin coupled liposomes by cultured porcine brain microvessel endothelial cells and intact brain capillaries. J. Drug Target 2002, 10, 337-344. [CrossRef]

111. Zheng, G.; Zheng, M.; Yang, B.; Fu, H.; Li, Y. Improving breast cancer therapy using doxorubicin loaded solid lipid nanoparticles: Synthesis of a novel arginine-glycine-aspartic tripeptide conjugated, $\mathrm{pH}$ sensitive lipid and evaluation of the nanomedicine in vitro and in vivo. Biomed. Pharmacother. 2019, 116, 109006. [CrossRef]

112. Kadari, A.; Pooja, D.; Gora, R.H.; Gudem, S.; Kolapalli, V.R.M.; Kulhari, H.; Sistla, R. Design of multifunctional peptide collaborated and docetaxel loaded lipid nanoparticles for antiglioma therapy. Eur. J. Pharm. Biopharm. 2018, 132, 168-179. [CrossRef]

113. Siddhartha, V.T.; Pindiprolu, S.K.S.; Chintamaneni, P.K.; Tummala, S.; Nandha Kumar, S. RAGE receptor targeted bioconjuguate lipid nanoparticles of diallyl disulfide for improved apoptotic activity in triple negative breast cancer: In vitro studies. Artif. Cells Nanomed. Biotechnol. 2018, 46, 387-397. [CrossRef] [PubMed]

114. Rajpoot, K.; Jain, S.K. Oral delivery of pH-responsive alginate microbeads incorporating folic acid-grafted solid lipid nanoparticles exhibits enhanced targeting effect against colorectal cancer: A dual-targeted approach. Int. J. Biol. Macromol. 2020, 151, 830-844. [CrossRef]

115. Kumar, C.S.; Thangam, R.; Mary, S.A.; Kannan, P.R.; Arun, G.; Madhan, B. Targeted delivery and apoptosis induction of trans-resveratrol-ferulic acid loaded chitosan coated folic acid conjugate solid lipid nanoparticles in colon cancer cells. Carbohydr. Polym. 2020, 231, 115682. [CrossRef]

116. Müller, R.; Schwarz, C.; Zur Mühlen, A.; Mehnert, W. Incorporation of lipophilic drugs and drug release profiles of solid lipid nanoparticles (SLN). Proceedings of International Symposium on Controlled Release of Bioactive Materials, Nice, France, 27-30 June 1994; pp. 146-147.

117. Zur Mühlen, A.; Mehnert, W. Drug release and release mechanism of prednisolone loaded solid lipid nanoparticles. Pharmazie 1998, 53, 552-555.

118. Schwarz, C.; Mehnert, W.; Lucks, J.; Müller, R. Solid lipid nanoparticles (SLN) for controlled drug delivery. I. Production, characterization and sterilization. J. Control. Release 1994, 30, 83-96. [CrossRef]

119. Battaglia, L.; Gallarate, M.; Panciani, P.P.; Ugazio, E.; Sapino, S.; Peira, E.; Chirio, D. Techniques for the preparation of solid lipid nano and microparticles. Appl. Nanotechnol. Drug Deliv. 2014, 1, 51-75.

120. Mehnert, W.; Mäder, K. Solid lipid nanoparticles: Production, characterization and applications. Adv. Drug Deliv. Rev. 2012, 64, 83-101. [CrossRef]

121. Mishra, V.; Bansal, K.K.; Verma, A.; Yadav, N.; Thakur, S.; Sudhakar, K.; Rosenholm, J.M. Solid lipid nanoparticles: Emerging colloidal nano drug delivery systems. Pharmaceutics 2018, 10, 191. [CrossRef]

122. Battaglia, L.; Trotta, M.; Cavalli, R. Method for the Preparation of Solid Micro and Nanoparticles. WIPO Patent WO2008149215, 11 December 2008.

123. Battaglia, L.; Gallarate, M.; Cavalli, R.; Trotta, M. Solid lipid nanoparticles produced through a coacervation method. J. Microencapsul. 2010, 27, 78-85. [CrossRef] [PubMed]

124. Bianco, M.; Gallarate, M.; Trotta, M.; Battaglia, L. Amphotericin B loaded SLN prepared with the coacervation technique. J. Drug Deliv. Sci. Technol. 2010, 20, 187-191. [CrossRef] 
125. Chirio, D.; Gallarate, M.; Peira, E.; Battaglia, L.; Serpe, L.; Trotta, M. Formulation of curcumin-loaded solid lipid nanoparticles produced by fatty acids coacervation technique. J. Microencapsul. 2011, 28, 537-548. [CrossRef]

126. Del Curto, M.; Chicco, D.; D'antonio, M.; Ciolli, V.; Dannan, H.; D’urso, S.; Neuteboom, B.; Pompili, S.; Schiesaro, S.; Esposito, P. Lipid microparticles as sustained release system for a GnRH antagonist (Antide). J. Control. Release 2003, 89, 297-310. [CrossRef]

127. Trotta, M.; Cavalli, R.; Trotta, C.; Bussano, R.; Costa, L. Electrospray technique for solid lipid-based particle production. Drug Dev. Ind. Pharm. 2010, 36, 431-438. [CrossRef]

128. Bussano, R.; Chirio, D.; Costa, L.; Turci, F.; Trotta, M. Preparation and characterization of insulin-loaded lipid-based microspheres generated by electrospray. J. Dispers. Sci. Technol. 2011, 32, 1524-1530. [CrossRef]

129. Byrappa, K.; Ohara, S.; Adschiri, T. Nanoparticles synthesis using supercritical fluid technology-towards biomedical applications. Adv. Drug Deliv. Rev. 2008, 60, 299-327. [CrossRef]

130. Müller, R.; Petersen, R.; Hommoss, A.; Pardeike, J. Nanostructured lipid carriers (NLC) in cosmetic dermal products. Adv. Drug Deliv. Rev. 2007, 59, 522-530. [CrossRef]

131. Müller, R.H.; Jenning, V.; Mader, K.; Lippacher, A. Lipid Particles on the Basis of Mixtures of Liquid and Solid Lipids and Method for Producing Same. US Patent US 8663692, 4 March 2014.

132. Dingler, A.; Gohla, S. Production of solid lipid nanoparticles (SLN): Scaling up feasibilities. J. Microencapsul. 2002, 19, 11-16. [CrossRef]

133. Zhang, S.-h.; Shen, S.-c.; Chen, Z.; Yun, J.-x.; Yao, K.-j.; Chen, B.-b.; Chen, J.-z. Preparation of solid lipid nanoparticles in co-flowing microchannels. Chem. Eng. J. 2008, 144, 324-328. [CrossRef]

134. Bodmeier, R.; Wang, J.; Bhagwatwar, H. Process and formulation variables in the preparation of wax microparticles by a melt dispersion technique. I. Oil-in-water technique for water-insoluble drugs. J. Microencapsul. 1992, 9, 89-98. [CrossRef]

135. Bodmeier, R.; Wang, J.; Bhagwatwar, H. Process and formulation variables in the preparation of wax microparticles by a melt dispersion technique. II. W/O/W multiple emulsion technique for water-soluble drugs. J. Microencapsul. 1992, 9, 99-107. [CrossRef]

136. Charcosset, C.; El-Harati, A.; Fessi, H. Preparation of solid lipid nanoparticles using a membrane contactor. J. Control. Release 2005, 108, 112-120. [CrossRef]

137. Ahmed El-Harati, A.; Charcosset, C.; Fessi, H. Influence of the formulation for solid lipid nanoparticles prepared with a membrane contactor. Pharm. Dev. Technol. 2006, 11, 153-157. [CrossRef]

138. Mumper, R.J.; Jay, M. Microemulsions as Precursors to Solid Nanoparticles. US Patent US 7153525, 26 December 2006.

139. Koziara, J.; Oh, J.; Akers, W.; Ferraris, S.; Mumper, R. Blood compatibility of cetyl alcohol/polysorbate-based nanoparticles. Pharm. Res. 2005, 22, 1821-1828. [CrossRef] [PubMed]

140. Oyewumi, M.O.; Mumper, R.J. Influence of formulation parameters on gadolinium entrapment and tumor cell uptake using folate-coated nanoparticles. Int. J. Pharm. 2003, 251, 85-97. [CrossRef]

141. Hoar, T.; Schulman, J. Transparent water-in-oil dispersions: The oleopathic hydro-micelle. Nature 1943, 152, 102-103. [CrossRef]

142. Attwood, D. Colloidal Drug Delivery Systems. Drugs Pharm. Sci. 1994, 66, 31-71.

143. Kreilgaard, M. Influence of microemulsions on cutaneous drug delivery. Adv. Drug Deliv. Rev. 2002, 54, S77-S98. [CrossRef]

144. Gasco, M.R. Method for Producing Solid Lipid Microspheres Having a Narrow Size Distribution. US Patent US5250236, 5 October 1993.

145. Morel, S.; Terreno, E.; Ugazio, E.; Aime, S.; Gasco, M.R. NMR relaxometric investigations of solid lipid nanoparticles (SLN) containing gadolinium (III) complexes. Eur. J. Pharm. Biopharm. 1998, 45, 157-163. [CrossRef]

146. Peira, E.; Marzola, P.; Podio, V.; Aime, S.; Sbarbati, A.; Gasco, M.R. In vitro and in vivo study of solid lipid nanoparticles loaded with superparamagnetic iron oxide. J. Drug Target. 2003, 11, 19-24. [CrossRef]

147. Salmaso, S.; Elvassore, N.; Bertucco, A.; Caliceti, P. Production of solid lipid submicron particles for protein delivery using a novel supercritical gas-assisted melting atomization process. J. Pharm. Sci. 2009, 98, 640-650. [CrossRef]

148. Vezzù, K.; Borin, D.; Bertucco, A.; Bersani, S.; Salmaso, S.; Caliceti, P. Production of lipid microparticles containing bioactive molecules functionalized with PEG. J. Supercrit. Fluids 2010, 54, 328-334. [CrossRef]

149. Bertucco, A.; Caliceti, P.; Elvassore, N. Process for the Production of Nanoparticles. WIPO Patent WO2007028421, 15 March 2007.

150. Shinoda, K.; Saito, H. The stability of O/W type emulsions as functions of temperature and the HLB of emulsifiers: The emulsification by PIT-method. J. Colloid Interface Sci. 1969, 30, 258-263. [CrossRef]

151. Huynh, N.T.; Passirani, C.; Saulnier, P.; Benoît, J.-P. Lipid nanocapsules: A new platform for nanomedicine. Int. J. Pharm. 2009, 379, 201-209. [CrossRef]

152. Montenegro, L.; Campisi, A.; Sarpietro, M.G.; Carbone, C.; Acquaviva, R.; Raciti, G.; Puglisi, G. In vitro evaluation of idebenoneloaded solid lipid nanoparticles for drug delivery to the brain. Drug Dev. Ind. Pharm. 2011, 37, 737-746. [CrossRef] [PubMed]

153. Berton, A.; Piel, G.; Evrard, B. Powdered lipid nano and microparticles: Production and applications. Recent Pat. Drug Deliv. Formul. 2011, 5, 188-200. [CrossRef] [PubMed]

154. Siekmann, B.; Westesen, K. Investigations on solid lipid nanoparticles prepared by precipitation in o/w emulsions. Eur. J. Pharm. Biopharm. 1996, 42, 104-109.

155. Trotta, M.; Debernardi, F.; Caputo, O. Preparation of solid lipid nanoparticles by a solvent emulsification-diffusion technique. Int. J. Pharm. 2003, 257, 153-160. [CrossRef] 
156. Garcia-Fuentes, M.; Torres, D.; Alonso, M. Design of lipid nanoparticles for the oral delivery of hydrophilic macromolecules. Colloids Surf. B Biointerfaces 2003, 27, 159-168. [CrossRef]

157. Gallarate, M.; Trotta, M.; Battaglia, L.; Chirio, D. Preparation of solid lipid nanoparticles from W/O/W emulsions: Preliminary studies on insulin encapsulation. J. Microencapsul. 2009, 26, 394-402. [CrossRef]

158. Schubert, M.; Müller-Goymann, C. Solvent injection as a new approach for manufacturing lipid nanoparticles-evaluation of the method and process parameters. Eur. J. Pharm. Biopharm. 2003, 55, 125-131. [CrossRef]

159. Hu, F.; Yuan, H.; Zhang, H.; Fang, M. Preparation of solid lipid nanoparticles with clobetasol propionate by a novel solvent diffusion method in aqueous system and physicochemical characterization. Int. J. Pharm. 2002, 239, 121-128. [CrossRef]

160. Rodriguez, L.; Cini, M.; Cavallari, C.; Motta, G. Apparatus and Method for Preparing Solid Forms with Controlled Release of the Active Ingredient. Australian Patent AU693539B2, 7 February 1998.

161. Passerini, N.; Qi, S.; Albertini, B.; Grassi, M.; Rodriguez, L.; Craig, D.Q. Solid lipid microparticles produced by spray congealing: Influence of the atomizer on microparticle characteristics and mathematical modeling of the drug release. J. Pharm. Sci. 2010, 99, 916-931. [CrossRef]

162. Killeen, M. Spray drying and spray congealing of pharmaceuticals. In Encyclopedia of Pharmaceutical Technology; Swarbrick, J., Boylan, J.C., Eds.; PharmaceuTech, Inc.; Informa Healthcare, Inc.: New York, NY, USA, 2000.

163. Pilcer, G.; Amighi, K. Formulation strategy and use of excipients in pulmonary drug delivery. Int. J. Pharm. 2010, 392, 1-19. [CrossRef]

164. Sebti, T.; Amighi, K. Preparation and in vitro evaluation of lipidic carriers and fillers for inhalation. Eur. J. Pharm. Biopharm. 2006, 63, 51-58. [CrossRef]

165. Chattopadhyay, P.; Shekunov, B.Y.; Seitzinger, J.S.; Huff, R.W. Particles from supercritical fluid extraction of emulsion. WIPO Patent WO2004004862A1, 15 January 2004.

166. Chattopadhyay, P.; Shekunov, B.Y.; Yim, D.; Cipolla, D.; Boyd, B.; Farr, S. Production of solid lipid nanoparticle suspensions using supercritical fluid extraction of emulsions (SFEE) for pulmonary delivery using the AERx system. Adv. Drug Deliv. Rev. 2007, 59, 444-453. [CrossRef]

167. Carlotti, M.E.; Sapino, S.; Trotta, M.; Battaglia, L.; Vione, D.; Pelizzetti, E. Photostability and stability over time of retinyl palmitate in an O/W emulsion and in SLN introduced in the emulsion. J. Dispers. Sci. Technol. 2005, 26, 125-138. [CrossRef]

168. Hou, D.; Xie, C.; Huang, K.; Zhu, C. The production and characteristics of solid lipid nanoparticles (SLNs). Biomaterials 2003, 24, 1781-1785. [CrossRef]

169. Corrias, F.; Lai, F. New methods for lipid nanoparticles preparation. Recent Pat. Drug Deliv. Formul. 2011, 5, 201-213. [CrossRef] [PubMed]

170. Speiser, P. Lipidnanopellets als Trägersystem für Arzneimittel zur peroralen Anwendung. European Patent 167825, 8 August 1990.

171. Ahlin, P.; Kristl, J.; Smid-Korbar, J. Optimization of procedure parameters and physical stability of solid lipid nanoparticles in dispersions. Acta Pharm. 1998, 48, 259-267.

172. Olbrich, C.; Gessner, A.; Kayser, O.; Müller, R.H. Lipid-drug-conjugate (LDC) nanoparticles as novel carrier system for the hydrophilic antitrypanosomal drug diminazenediaceturate. J. Drug Target. 2002, 10, 387-396. [CrossRef]

173. Eldem, T.; Speiser, P.; Hincal, A. Optimization of spray-dried and-congealed lipid micropellets and characterization of their surface morphology by scanning electron microscopy. Pharm. Res. 1991, 8, 47-54. [CrossRef]

174. Tan, M.-e.; He, C.-h.; Jiang, W.; Zeng, C.; Yu, N.; Huang, W.; Gao, Z.-g.; Xing, J.-g. Development of solid lipid nanoparticles containing total flavonoid extract from Dracocephalum moldavica L. and their therapeutic effect against myocardial ischemiareperfusion injury in rats. Int. J. Nanomed. 2017, 12, 3253. [CrossRef]

175. Lander, R.; Manger, W.; Scouloudis, M.; Ku, A.; Davis, C.; Lee, A. Gaulin homogenization: A mechanistic study. Biotechnol. Prog. 2000, 16, 80-85. [CrossRef]

176. Müller, R.H.; Benita, S.; Bohm, B. Emulsions and Nanosuspensions for the Formulation of Poorly Soluble Drugs; CRC Press: Boca Raton, FL, USA, 1998.

177. zur Muhlen, A. Feste Lipid Nanopartikel mit Prolongierter Wirkstoffliberation: Herstellung, Langzeitstabilität, Charakterisierung, Freisetzungsverhalten und Mechanismen. Ph.D. Thesis, Free University of Berlin, Berlin, Germany, 1996.

178. Sjöström, B.; Bergenståhl, B. Preparation of submicron drug particles in lecithin-stabilized ow emulsions: I. Model studies of the precipitation of cholesteryl acetate. Int. J. Pharm. 1992, 84, 107-116. [CrossRef]

179. Cavalli, R.; Marengo, E.; Rodriguez, L.; Gasco, M.R. Effects of some experimental factors on the production process of solid lipid nanoparticles. Eur. J. Pharm. Biopharm. 1996, 42, 110-115.

180. Chen, Y.; Jin, R.; Zhou, Y.; Zeng, J.; Zhang, H.; Feng, Q. Preparation of solid lipid nanoparticles loaded with Xionggui powdersupercritical carbon dioxide fluid extraction and their evaluation in vitro release. Zhongguo Zhongyao Zazhi China J. Chin. Mater. Med. 2006, 31, 376-379.

181. Meyer, W. Wettkampf und Spiel in den Miniaturen der Manessischen Liederhandschrift. Stadion 1988, $14,1-48$.

182. Gosselin, P.; Thibert, R.; Preda, M.; McMullen, J. Polymorphic properties of micronized carbamazepine produced by RESS. Int. J. Pharm. 2003, 252, 225-233. [CrossRef]

183. Freitas, C.; Müller, R.H. Spray-drying of solid lipid nanoparticles (SLNTM). Eur. J. Pharm. Biopharm. 1998, 46, 145-151. [CrossRef]

184. Sguizzato, M.; Esposito, E.; Drechsler, M.; Gallerani, E.; Gavioli, R.; Mariani, P.; Carducci, F.; Cortesi, R.; Bergamini, P. Nafion ${ }^{\circledR}-$ Containing Solid Lipid Nanoparticles as a Tool for Anticancer Pt Delivery: Preliminary Studies. J. Chem. 2017, 2017. [CrossRef] 
185. Cortesi, R.; Esposito, E.; Luca, G.; Nastruzzi, C. Production of lipospheres as carriers for bioactive compounds. Biomaterials 2002, 23, 2283-2294. [CrossRef]

186. Heurtault, B.; Saulnier, P.; Benoit, J.-P.; Proust, J.-E.; Pech, B.; Richard, J. Lipid Nanocapsules, Preparation Process and Use as Medicine. US Patent US8057823B2, 15 November 2011.

187. Mori, N.; Sheth, N.; Mendapara, V.; Ashara, K.; Paun, J. SLN brain targeting drug delivery for CNS: A novel approach. Int. Res. J. Pharm 2014, 5, 658-662. [CrossRef]

188. Battaglia, L.; Serpe, L.; Foglietta, F.; Muntoni, E.; Gallarate, M.; Del Pozo Rodriguez, A.; Solinis, M.A. Application of lipid nanoparticles to ocular drug delivery. Expert Opin. Drug Deliv. 2016, 13, 1743-1757. [CrossRef] [PubMed]

189. Vakilinezhad, M.A.; Amini, A.; Javar, H.A.; Zarandi, B.F.B.a.B.; Montaseri, H.; Dinarvand, R. Nicotinamide loaded functionalized solid lipid nanoparticles improves cognition in Alzheimer's disease animal model by reducing Tau hyperphosphorylation. DARU J. Pharm. Sci. 2018, 26, 165-177. [CrossRef] [PubMed]

190. Saini, S.; Sharma, T.; Jain, A.; Kaur, H.; Katare, O.; Singh, B. Systematically designed chitosan-coated solid lipid nanoparticles of ferulic acid for effective management of Alzheimer's disease: A preclinical evidence. Colloids Surf. B Biointerfaces 2021, 205, 111838. [CrossRef]

191. Misra, S.; Kuhad, A.; Kaur, I.; Chopra, K. Neuroprotective potential of solid lipid nanoparticles of sesamol: Possible brain targeting strategy. Alzheimers Dement. 2012, 8, P199. [CrossRef]

192. Nelluri, S.; Felix, J.; Sathesh, K. Formulation and evaluation of galantamine nanoparticles for neurological disorders. Int. J. Pharm. Chem. Biol. Sci. 2015, 5, 63-70.

193. Dhawan, S.; Kapil, R.; Singh, B. Formulation development and systematic optimization of solid lipid nanoparticles of quercetin for improved brain delivery. J. Pharm. Pharmacol. 2011, 63, 342-351. [CrossRef] [PubMed]

194. Yusuf, M.; Khan, M.; Khan, R.A.; Ahmed, B. Preparation, characterization, in vivo and biochemical evaluation of brain targeted Piperine solid lipid nanoparticles in an experimentally induced Alzheimer's disease model. J. Drug Target. 2013, $21,300-311$. [CrossRef]

195. Orlando, A.; Re, F.; Sesana, S.; Rivolta, I.; Panariti, A.; Brambilla, D.; Nicolas, J.; Couvreur, P.; Andrieux, K.; Masserini, M. Effect of nanoparticles binding $\beta$-amyloid peptide on nitric oxide production by cultured endothelial cells and macrophages. Int. $J$. Nanomed. 2013, 8, 1335.

196. Picone, P.; Bondi, M.L.; Picone, P.; Bondi, M.L.; Montana, G.; Bruno, A.; Pitarresi, G.; Giammona, G.; Di Carlo, M. Ferulic acid inhibits oxidative stress and cell death induced by Ab oligomers: Improved delivery by solid lipid nanoparticles. Free Radic. Res. 2009, 43, 1133-1145. [CrossRef]

197. Smith, A.; Giunta, B.; Bickford, P.C.; Fountain, M.; Tan, J.; Shytle, R.D. Nanolipidic particles improve the bioavailability and $\alpha$-secretase inducing ability of epigallocatechin-3-gallate (EGCG) for the treatment of Alzheimer's disease. Int. J. Pharm. 2010, 389, 207-212. [CrossRef]

198. Kakkar, V.; Kaur, I.P. Evaluating potential of curcumin loaded solid lipid nanoparticles in aluminium induced behavioural, biochemical and histopathological alterations in mice brain. Food Chem. Toxicol. 2011, 49, 2906-2913. [CrossRef]

199. Zhan, S.M.; Hou, D.Z.; Ping, Q.N.; Xu, Y. Preparation and entrapment efficiency determination of solid lipid nanoparticles loaded levodopa. Chin. J. Hosp. Pharm. 2010, 14, 1171-1175.

200. Esposito, E.; Fantin, M.; Marti, M.; Drechsler, M.; Paccamiccio, L.; Mariani, P.; Sivieri, E.; Lain, F.; Menegatti, E.; Morari, M. Solid lipid nanoparticles as delivery systems for bromocriptine. Pharm. Res. 2008, 25, 1521-1530. [CrossRef]

201. Tsai, M.-J.; Huang, Y.-B.; Wu, P.-C.; Fu, Y.-S.; Kao, Y.-R.; Fang, J.-Y.; Tsai, Y.-H. Oral apomorphine delivery from solid lipid nanoparticles with different monostearate emulsifiers: Pharmacokinetic and behavioral evaluations. J. Pharm. Sci. 2011, 100, 547-557. [CrossRef]

202. Pardeshi, C.V.; Rajput, P.V.; Belgamwar, V.S.; Tekade, A.R.; Surana, S.J. Novel surface modified solid lipid nanoparticles as intranasal carriers for ropinirole hydrochloride: Application of factorial design approach. Drug Deliv. 2013, 20, 47-56. [CrossRef] [PubMed]

203. Sandhir, R.; Yadav, A.; Mehrotra, A.; Sunkaria, A.; Singh, A.; Sharma, S. Curcumin nanoparticles attenuate neurochemical and neurobehavioral deficits in experimental model of Huntington's disease. Neuromolecular Med. 2014, 16, 106-118. [CrossRef]

204. Bhatt, R.; Singh, D.; Prakash, A.; Mishra, N. Development, characterization and nasal delivery of rosmarinic acid-loaded solid lipid nanoparticles for the effective management of Huntington's disease. Drug Deliv. 2015, 22, 931-939. [CrossRef]

205. des Rieux, A.; Fievez, V.; Garinot, M.; Schneider, Y.-J.; Préat, V. Nanoparticles as potential oral delivery systems of proteins and vaccines: A mechanistic approach. J. Control. Release 2006, 116, 1-27. [CrossRef]

206. Garcion, E.; Lamprecht, A.; Heurtault, B.; Paillard, A.; Aubert-Pouessel, A.; Denizot, B.; Menei, P.; Benoît, J.-P. A new generation of anticancer, drug-loaded, colloidal vectors reverses multidrug resistance in glioma and reduces tumor progression in rats. Mol. Cancer Ther. 2006, 5, 1710-1722. [CrossRef]

207. Blasi, P.; Giovagnoli, S.; Schoubben, A.; Ricci, M.; Rossi, C. Solid lipid nanoparticles for targeted brain drug delivery. Adv. Drug Deliv. Rev. 2007, 59, 454-477. [CrossRef]

208. Wong, H.L.; Wu, X.Y.; Bendayan, R. Nanotechnological advances for the delivery of CNS therapeutics. Adv. Drug Deliv. Rev. 2012, 64, 686-700. [CrossRef]

209. Samia, O.; Hanan, R.; Kamal, E.T. Carbamazepine mucoadhesive nanoemulgel (MNEG) as brain targeting delivery system via the olfactory mucosa. Drug Deliv. 2012, 19, 58-67. [CrossRef] 
210. Abdelbary, G.; Fahmy, R.H. Diazepam-loaded solid lipid nanoparticles: Design and characterization. Aaps Pharmscitech. 2009, 10, 211-219. [CrossRef]

211. Leyva-Gómez, G.; González-Trujano, M.E.; López-Ruiz, E.; Couraud, P.-O.; Wekslerg, B.; Romero, I.; Miller, F.; Delie, F.; Allémann, E.; Quintanar-Guerrero, D. Nanoparticle formulation improves the anticonvulsant effect of clonazepam on the pentylenetetrazoleinduced seizures: Behavior and electroencephalogram. J. Pharm. Sci. 2014, 103, 2509-2519. [CrossRef] [PubMed]

212. Tran, T.H.; Ramasamy, T.; Cho, H.J.; Kim, Y.I.; Poudel, B.K.; Choi, H.-G.; Yong, C.S.; Kim, J.O. Formulation and optimization of raloxifene-loaded solid lipid nanoparticles to enhance oral bioavailability. J. Nanosci. Nanotechnol. 2014, 14, 4820-4831. [CrossRef]

213. Vickers, N.J. Animal communication: When i'm calling you, will you answer too? Curr. Biol. 2017, 27, R713-R715. [CrossRef] [PubMed]

214. Gao, Y.; Gu, W.; Chen, L.; Xu, Z.; Li, Y. The role of daidzein-loaded sterically stabilized solid lipid nanoparticles in therapy for cardio-cerebrovascular diseases. Biomaterials 2008, 29, 4129-4136. [CrossRef]

215. Morsi, N.M.; Ghorab, D.M.; Badie, H.A. Brain targeted solid lipid nanoparticles for brain ischemia: Preparation and in vitro characterization. Pharm. Dev. Technol. 2013, 18, 736-744. [CrossRef] [PubMed]

216. Frautschy, S.A.; Cole, G.M. Bioavailable Curcuminoid Formulations for Treating Alzheimer's Disease and Other Age-Related Disorders. US Patent US20090324703A1, 24 November 2015.

217. Dang, H.; Meng, M.H.W.; Zhao, H.; Iqbal, J.; Dai, R.; Deng, Y.; Lv, F. Luteolin-loaded solid lipid nanoparticles synthesis, characterization, \& improvement of bioavailability, pharmacokinetics in vitro and vivo studies. J. Nanoparticle Res. 2014, 16, 1-10.

218. Burlá, C.; Rego, G.; Nunes, R. Alzheimer, dementia and the living will: A proposal. Med. Health Care Philos. 2014, 17, 389-395. [CrossRef]

219. Saykin, A.J.; Wishart, H.A.; Rabin, L.A.; Flashman, L.A.; McHugh, T.L.; Mamourian, A.C.; Santulli, R.B. Cholinergic enhancement of frontal lobe activity in mild cognitive impairment. Brain 2004, 127, 1574-1583. [CrossRef]

220. Yiannopoulou, K.; Papageorgiou, S. Current and future treatments for Alzheimer's disease. Ther. Adv. Neurol. Disord. 2013, 6, 19-33. [CrossRef]

221. Cacciatore, I.; Baldassarre, L.; Fornasari, E.; Cornacchia, C.; Di Stefano, A.; Sozio, P.; Cerasa, L.S.; Fontana, A.; Fulle, S.; Di Filippo, E.S. (R)- $\alpha$-Lipoyl-Glycyl-L-Prolyl-L-Glutamyl Dimethyl Ester Codrug as a Multifunctional Agent with Potential Neuroprotective Activities. ChemMedChem 2012, 7, 2021-2029. [CrossRef]

222. Sozio, P.; D'Aurizio, E.; Iannitelli, A.; Cataldi, A.; Zara, S.; Cantalamessa, F.; Nasuti, C.; Di Stefano, A. Ibuprofen and lipoic acid diamides as potential codrugs with neuroprotective activity. Arch. Der Pharm. Int. J. Pharm. Med. Chem. 2010, 343, 133-142. [CrossRef] [PubMed]

223. Topal, G.R.; Mészáros, M.; Porkoláb, G.; Szecskó, A.; Polgár, T.F.; Siklós, L.; Deli, M.A.; Veszelka, S.; Bozkir, A. ApoE-Targeting Increases the Transfer of Solid Lipid Nanoparticles with Donepezil Cargo across a Culture Model of the Blood-Brain Barrier. Pharmaceutics 2021, 13, 38. [CrossRef]

224. Wang, J.; Zhu, R.; Sun, D.; Sun, X.; Geng, Z.; Liu, H.; Wang, S.-L. Intracellular uptake of curcumin-loaded solid lipid nanoparticles exhibit anti-inflammatory activities superior to those of curcumin through the NF-kB signaling pathway. J. Biomed. Nanotechnol. 2015, 11, 403-415. [CrossRef] [PubMed]

225. Wang, J.; Wang, H.; Zhu, R.; Liu, Q.; Fei, J.; Wang, S. Anti-inflammatory activity of curcumin-loaded solid lipid nanoparticles in IL-1 $\beta$ transgenic mice subjected to the lipopolysaccharide-induced sepsis. Biomaterials 2015, 53, 475-483. [CrossRef]

226. Gaur, P.K.; Mishra, S.; Verma, A.; Verma, N. Ceramide-palmitic acid complex based Curcumin solid lipid nanoparticles for transdermal delivery: Pharmacokinetic and pharmacodynamic study. J. Exp. Nanosci. 2016, 11, 38-53. [CrossRef]

227. Rajput, A. Frequency and cause of Parkinson's disease. Can. J. Neurol. Sci. 1992, 19, 103-107. [CrossRef]

228. Cacciatore, I.; Ciulla, M.; Fornasari, E.; Marinelli, L.; Di Stefano, A. Solid lipid nanoparticles as a drug delivery system for the treatment of neurodegenerative diseases. Expert Opin. Drug Deliv. 2016, 13, 1121-1131. [CrossRef]

229. Sozio, P.; Iannitelli, A.; Cerasa, L.S.; Cacciatore, I.; Cornacchia, C.; Giorgioni, G.; Ricciutelli, M.; Nasuti, C.; Cantalamessa, F.; Di Stefano, A. New L-dopa codrugs as potential antiparkinson agents. Arch. Der Pharm. Int. J. Pharm. Med. Chem. 2008, 341, $412-417$. [CrossRef]

230. Minelli, A.; Conte, C.; Cacciatore, I.; Cornacchia, C.; Pinnen, F. Molecular mechanism underlying the cerebral effect of Gly-Pro-Glu tripeptide bound to L-dopa in a Parkinson's animal model. Amino Acids 2012, 43, 1359-1367. [CrossRef] [PubMed]

231. Minelli, A.; Conte, C.; Prudenzi, E.; Cacciatore, I.; Cornacchia, C.; Taha, E.; Pinnen, F. N-Acetyl-L-Methionyl-L-Dopa-Methyl Ester as a dual acting drug that relieves L-Dopa-induced oxidative toxicity. Free Radic. Biol. Med. 2010, 49, 31-39. [CrossRef]

232. Jankovic, J.; Stacy, M. Medical management of levodopa-associated motor complications in patients with Parkinson's disease. CNS Drugs 2007, 21, 677-692. [CrossRef]

233. Cingolani, G.M.; Di Stefano, A.; Mosciatti, B.; Napolitani, F.; Giorgioni, G.; Ricciutelli, M.; Claudi, F. Synthesis of L-(+)-3-(3hydroxy-4-pivaloyloxybenzyl)-2, 5-diketomorpholine as potential prodrug of L-dopa. Bioorganic Med. Chem. Lett. 2000, 10, 1385-1388. [CrossRef]

234. Neri-Nani, G.; López-Ruiz, M.; Estrada-Bellmann, I.; Carrasco, H.; Enríquez-Coronel, G.; González-Usigli, H.; Leal-Ortega, R.; Otero-Cerdeira, E.; Rodríguez, R.; Pedro, A.A. Mexican consensus on the diagnosis of Huntington's disease. Arch. Neurocienc. 2016, 21, 64-72. [CrossRef]

235. National Institute of Neurological Disorders and Stroke. Parkinson's Disease: Hope through Research; National Institute of Neurological Disorders and Stroke: Bethesda, MD, USA, 1994. 
236. Sturchio, A.; Marsili, L.; Mahajan, A.; Grimberg, M.; Kauffman, M.A.; Espay, A.J. How have advances in genetic technology modified movement disorder nosology? Eur. J. Neurol. 2020, 27, 1461-1470. [CrossRef] [PubMed]

237. Hachinski, V.; Iadecola, C.; Petersen, R.C.; Breteler, M.M.; Nyenhuis, D.L.; Black, S.E.; Powers, W.J.; DeCarli, C.; Merino, J.G.; Kalaria, R.N. National Institute of Neurological Disorders and Stroke-Canadian stroke network vascular cognitive impairment harmonization standards. Stroke 2006, 37, 2220-2241. [CrossRef] [PubMed]

238. Kappos, L.; Gold, R.; Miller, D.H.; MacManus, D.G.; Havrdova, E.; Limmroth, V.; Polman, C.H.; Schmierer, K.; Yousry, T.A.; Yang, M. Efficacy and safety of oral fumarate in patients with relapsing-remitting multiple sclerosis: A multicentre, randomised, double-blind, placebo-controlled phase IIb study. Lancet 2008, 372, 1463-1472. [CrossRef]

239. Salzer, J.; Svenningsson, A.; Sundström, P. Neurofilament light as a prognostic marker in multiple sclerosis. Mult. Scler. J. 2010, 16, 287-292. [CrossRef] [PubMed]

240. Michaeli, M.F.; Ahi, G.; Ramazani, F.; Behnejad, S. The effect of a pain management program in reducing the pain in patients with multiple sclerosis. J. Res. Health 2016, 6, 336-344.

241. Holden, C.A.; Yuan, Q.; Yeudall, W.A.; Lebman, D.A.; Yang, H. Surface engineering of macrophages with nanoparticles to generate a cell-nanoparticle hybrid vehicle for hypoxia-targeted drug delivery. Int. J. Nanomed. 2010, 5, 25.

242. Sanai, N.; Berger, M.S. Glioma extent of resection and its impact on patient outcome. Neurosurgery 2008, 62, 753-766. [CrossRef]

243. Özdemir, Y.G.; Pehlivan, S.B.; Sekerdag, E. Nanotechnology Methods for Neurological Diseases and Brain Tumors: Drug Delivery Across the Blood-Brain Barrier; Academic Press: Cambridge, MA, USA, 2017.

244. Bidros, D.S.; Vogelbaum, M.A. Novel drug delivery strategies in neuro-oncology. Neurotherapeutics 2009, 6, 539-546. [CrossRef] [PubMed]

245. Leslie-Barbick, J.E.; Saik, J.E.; Gould, D.J.; Dickinson, M.E.; West, J.L. The promotion of microvasculature formation in poly (ethylene glycol) diacrylate hydrogels by an immobilized VEGF-mimetic peptide. Biomaterials 2011, 32, 5782-5789. [CrossRef] [PubMed]

246. Kuo, Y.-C.; Liang, C.-T. Catanionic solid lipid nanoparticles carrying doxorubicin for inhibiting the growth of U87MG cells. Colloids Surf. B Biointerfaces 2011, 85, 131-137. [CrossRef] [PubMed]

247. Gonçalves, M.; Mignani, S.; Rodrigues, J.; Tomás, H. A glance over doxorubicin based-nanotherapeutics: From proof-of-concept studies to solutions in the market. J. Control. Release 2020, 317, 347-374. [CrossRef]

248. Kuo, Y.-C.; Lee, C.-H. Inhibition against growth of glioblastoma multiforme in vitro using etoposide-loaded solid lipid nanoparticles with $\rho$-Aminophenyl- $\alpha$-D-manno-pyranoside and folic acid. J. Pharm. Sci. 2015, 104, 1804-1814. [CrossRef]

249. Kuo, Y.-C.; Wang, I.-H. Enhanced delivery of etoposide across the blood-brain barrier to restrain brain tumor growth using melanotransferrin antibody-and tamoxifen-conjugated solid lipid nanoparticles. J. Drug Target. 2016, 24, 645-654. [CrossRef] [PubMed]

250. de Mendoza, A.E.-H.; Préat, V.; Mollinedo, F.; Blanco-Prieto, M.J. In vitro and in vivo efficacy of edelfosine-loaded lipid nanoparticles against glioma. J. Control. Release 2011, 156, 421-426. [CrossRef]

251. Martins, S.; Costa-Lima, S.; Carneiro, T.; Cordeiro-da-Silva, A.; Souto, E.; Ferreira, D. Solid lipid nanoparticles as intracellular drug transporters: An investigation of the uptake mechanism and pathway. Int. J. Pharm. 2012, 430, 216-227. [CrossRef]

252. Jose, S.; Anju, S.; Cinu, T.; Aleykutty, N.; Thomas, S.; Souto, E. In vivo pharmacokinetics and biodistribution of resveratrol-loaded solid lipid nanoparticles for brain delivery. Int. J. Pharm. 2014, 474, 6-13. [CrossRef]

253. Chirio, D.; Gallarate, M.; Peira, E.; Battaglia, L.; Muntoni, E.; Riganti, C.; Biasibetti, E.; Capucchio, M.T.; Valazza, A.; Panciani, P. Positive-charged solid lipid nanoparticles as paclitaxel drug delivery system in glioblastoma treatment. Eur. J. Pharm. Biopharm. 2014, 88, 746-758. [CrossRef] [PubMed]

254. Jabir, N.R.; Tabrez, S.; Firoz, C.; Kashif Zaidi, S.; Baeesa, S.S.; Hua Gan, S.; Shakil, S.; Amjad Kamal, M. A synopsis of nanotechnological approaches toward anti-epilepsy therapy: Present and future research implications. Curr. Drug Metab. 2015, 16, 336-345. [CrossRef] [PubMed]

255. Bennewitz, M.F.; Saltzman, W.M. Nanotechnology for delivery of drugs to the brain for epilepsy. Neurotherapeutics 2009, 6 , 323-336. [CrossRef]

256. Kohane, D.S.; Holmes, G.L.; Chau, Y.; Zurakowski, D.; Langer, R.; Cha, B.H. Effectiveness of muscimol-containing microparticles against pilocarpine-induced focal seizures. Epilepsia 2002, 43, 1462-1468. [CrossRef]

257. Ali, A.; Pillai, K.K.; Ahmad, F.J.; Dua, Y.; Khan, Z.I.; Vohora, D. Comparative efficacy of liposome-entrapped amiloride and free amiloride in animal models of seizures and serum potassium in mice. Eur. Neuropsychopharmacol. 2007, 17, 227-229. [CrossRef] [PubMed]

258. Lakhan, S.E.; Kirchgessner, A.; Hofer, M. Inflammatory mechanisms in ischemic stroke: Therapeutic approaches. J. Transl. Med. 2009, 7, 1-11. [CrossRef]

259. Sacco, R.L.; Kasner, S.E.; Broderick, J.P.; Caplan, L.R.; Connors, J.; Culebras, A.; Elkind, M.S.; George, M.G.; Hamdan, A.D.; Higashida, R.T. An updated definition of stroke for the 21st century: A statement for healthcare professionals from the American Heart Association/American Stroke Association. Stroke 2013, 44, 2064-2089. [CrossRef]

260. Choi, D.W.; Rothman, S.M. The role of glutamate neurotoxicity in hypoxic-ischemic neuronal death. Annu. Rev. Neurosci. 1990, 13, 171-182. [CrossRef]

261. Rego, A.C.; Oliveira, C.R. Mitochondrial dysfunction and reactive oxygen species in excitotoxicity and apoptosis: Implications for the pathogenesis of neurodegenerative diseases. Neurochem. Res. 2003, 28, 1563-1574. [CrossRef] 
262. Thompson, B.J.; Ronaldson, P.T. Drug delivery to the ischemic brain. Adv. Pharmacol. 2014, 71, 165-202.

263. González-Nieto, D.; Fernández-Serra, R.; Pérez-Rigueiro, J.; Panetsos, F.; Martinez-Murillo, R.; Guinea, G.V. Biomaterials to neuroprotect the stroke brain: A large opportunity for narrow time windows. Cells 2020, 9, 1074. [CrossRef] [PubMed]

264. Sarmah, D.; Saraf, J.; Kaur, H.; Pravalika, K.; Tekade, R.K.; Borah, A.; Kalia, K.; Dave, K.R.; Bhattacharya, P. Stroke management: An emerging role of nanotechnology. Micromachines 2017, 8, 262. [CrossRef] [PubMed]

265. Crielaard, B.; Lammers, T.; Morgan, M.; Chaabane, L.; Carboni, S.; Greco, B.; Zaratin, P.; Kraneveld, A.; Storm, G. Macrophages and liposomes in inflammatory disease: Friends or foes? Int. J. Pharm. 2011, 416, 499-506. [CrossRef] [PubMed]

266. Kakkar, V.; Muppu, S.K.; Chopra, K.; Kaur, I.P. Curcumin loaded solid lipid nanoparticles: An efficient formulation approach for cerebral ischemic reperfusion injury in rats. Eur. J. Pharm. Biopharm. 2013, 85, 339-345. [CrossRef]

267. Tsai, M.-J.; Wu, P.-C.; Huang, Y.-B.; Chang, J.-S.; Lin, C.-L.; Tsai, Y.-H.; Fang, J.-Y. Baicalein loaded in tocol nanostructured lipid carriers (tocol NLCs) for enhanced stability and brain targeting. Int. J. Pharm. 2012, 423, 461-470. [CrossRef]

268. Neves, A.R.; Queiroz, J.F.; Reis, S. Brain-targeted delivery of resveratrol using solid lipid nanoparticles functionalized with apolipoprotein E. J. Nanobiotechnology 2016, 14, 1-11. [CrossRef]

269. Hassanzadeh, P.; Arbabi, E.; Atyabi, F.; Dinarvand, R. Ferulic acid-loaded nanostructured lipid carriers: A promising nanoformulation against the ischemic neural injuries. Life Sci. 2018, 193, 64-76. [CrossRef]

270. Moosmann, B.; Behl, C. Antioxidants as treatment for neurodegenerative disorders. Expert Opin. Investig. Drugs 2002, 11, 1407-1435. [CrossRef] [PubMed]

271. Cacciatore, I.; Caccuri, A.; Di Stefano, A.; Luisi, G.; Nalli, M.; Pinnen, F.; Ricci, G.; Sozio, P. Synthesis and activity of novel glutathione analogues containing an urethane backbone linkage. Il Farm. 2003, 58, 787-793. [CrossRef]

272. Souto, E.; Müller, R.; Gohla, S. A novel approach based on lipid nanoparticles (SLN@) for topical delivery of $\alpha$-lipoic acid. J. Microencapsul. 2005, 22, 581-592. [CrossRef]

273. Laserra, S.; Basit, A.; Sozio, P.; Marinelli, L.; Fornasari, E.; Cacciatore, I.; Ciulla, M.; Türkez, H.; Geyikoglu, F.; Di Stefano, A. Solid lipid nanoparticles loaded with lipoyl-memantine codrug: Preparation and characterization. Int. J. Pharm. 2015, 485, 183-191. [CrossRef]

274. Duarte, A.M.G. Resveratrol and Grape's Extract-Loaded Solid Lipid Nanoparticles for the Treatment of Parkinson's and Alzheimer's Diseases. Master's Thesis, Faculty of Engineering of University of Porto, Porto, Portugal, 2015.

275. Loureiro, J.A.; Andrade, S.; Duarte, A.; Neves, A.R.; Queiroz, J.F.; Nunes, C.; Sevin, E.; Fenart, L.; Gosselet, F.; Coelho, M.A.N.; et al. Resveratrol and Grape Extract-loaded Solid Lipid Nanoparticles for the Treatment of Alzheimer's Disease. Molecules 2017, 22, 277. [CrossRef] [PubMed]

276. Fernandes, F.; Dias-Teixeira, M.; Delerue-Matos, C.; Grosso, C. Critical Review of Lipid-Based Nanoparticles as Carriers of Neuroprotective Drugs and Extracts. Nanomaterials 2021, 11, 563. [CrossRef] [PubMed]

277. Thi, T.T.H.; Suys, E.J.; Lee, J.S.; Nguyen, D.H.; Park, K.D.; Truong, N.P. Lipid-Based Nanoparticles in the Clinic and Clinical Trials: From Cancer Nanomedicine to COVID-19 Vaccines. Vaccines 2021, 9, 359. [CrossRef] [PubMed]

278. Mistraletti, G.; Paroni, R.; Umbrello, M.; Moro Salihovic, B.; Coppola, S.; Froio, S.; Finati, E.; Gasco, P.; Savoca, A.; Manca, D. Different routes and formulations of melatonin in critically ill patients. A pharmacokinetic randomized study. Clin. Endocrinol. 2019, 91, 209-218. [CrossRef] [PubMed] 